\title{
Status of aquatic and riparian biodiversity in artificial lake ecosystems with and without management for recreational fisheries: Implications for conservation
}

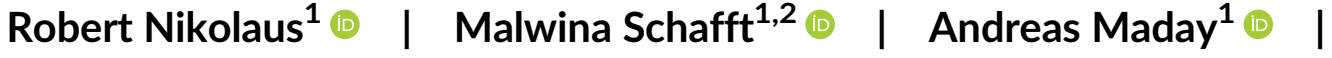 \\ Thomas Klefoth $^{3}$ (ㄷ) | Christian Wolter ${ }^{1}$ () | Robert Arlinghaus ${ }^{1,2}$ ()
}

\author{
${ }^{1}$ Department of Biology and Ecology of Fishes, \\ Leibniz Institute of Freshwater Ecology and \\ Inland Fisheries, Berlin, Germany \\ ${ }^{2}$ Division for Integrative Fisheries \\ Management, Albrecht Daniel Thaer Institute \\ of Agriculture and Horticulture, Humboldt- \\ Universität zu Berlin, Berlin, Germany \\ ${ }^{3}$ Ecology and Conservation, Faculty of Nature \\ and Engineering, Hochschule Bremen, City \\ University of Applied Sciences, Bremen, \\ Germany
}

\section{Correspondence}

Robert Nikolaus, Department of Biology and

Ecology of Fishes, Leibniz Institute of

Freshwater Ecology and Inland Fisheries,

Müggelseedamm 310, Berlin D-12587,

Germany.

Email: nikolaus@igb-berlin.de

Funding information

Bundesministerium für Bildung und Forschung, Grant/Award Numbers: 01LC1320A,

01LC1826E; the German Federal Agency for Nature Conservation (BfN) with funds granted by the German Federal Ministry for the Environment, Nature Conservation and Nuclear Safety (BMU); the Stiftung Fischerei, Umwelt- und Naturschutz Deutschland (FUND Stiftung) the Landesverband Sächsischer Angler e.V.; the Landesfischereiverband Bayern e.V.; the Angling Association of Lower Saxony

\section{Abstract}

1. Humanity is facing a biodiversity crisis, with freshwater-associated biodiversity in a particularly dire state. Novel ecosystems created through human use of mineral resources, such as gravel pit lakes, can provide substitute habitats for the conservation of freshwater and riparian biodiversity. Many of these artificial ecosystems are subject to a high intensity of recreational use, however, which may limit their biodiversity potential.

2. The species richness of several taxa (plants, amphibians, dragonflies, damselflies, waterfowl, and songbirds) was assessed and a range of taxonomic biodiversity metrics were compared between gravel pit lakes managed for recreational fisheries $(n=16)$ and unmanaged reference lakes $(n=10)$, controlling for non-fishingrelated environmental variation.

3. The average species richness of all the taxa examined was similar among lakes in both lake types and no substantial differences in species composition were found when examining the pooled species inventory. Similarly, there were no differences between lake types in the presence of rare species and in the Simpson diversity index across all of the taxa assessed.

4. Variation in species richness among lakes was correlated with woody habitat, lake morphology (surface area and steepness), and land use, but was not correlated with the presence of recreational fisheries. Thus, non-fishing-related environmental variables had stronger effects on local species presence than recreational fisheries management or the presence of recreational anglers.

5. Collectively, no evidence was found that anglers and recreational fisheries management constrain the development of aquatic and riparian biodiversity in gravel pit lakes in the study region; however, the conservation of species diversity in gravel pit lakes could benefit from an increasing reliance on habitat enhancement activities. 


\section{KEYWORDS}

amphibians, biodiversity, birds, disturbance, fishing, lake, littoral, recreation, riparian,

vegetation

\section{1 | INTRODUCTION}

Globally, biodiversity is in steep decline, with an estimated 1 million species currently threatened by extinction (Díaz et al., 2019). The biodiversity decline is particularly prevalent in fresh waters (Reid et al., 2019), where habitat alteration and fragmentation, pollution, biological invasions, and climate change are key drivers (Dudgeon et al., 2006).

Artificially created aquatic habitats, such as gravel pit lakes or ponds, could maintain and increase native freshwater biodiversity by providing refuge and secondary habitats for rare or endangered species (Damnjanović et al., 2018; Oertli, 2018). The origins of artificial lake ecosystems are often relatively recent (less than 100 years of age; Zhao, Grenouillet, Pool, Tudesque, \& Cucherousset, 2016), where artificial lakes are often created by mining for mineral resources (Saulnier-Talbot \& Lavoie, 2018). More than $1 \times 10^{9} \mathrm{t}$ of sand and gravel were excavated in more than 24,500 quarries and pits within the European Union in 2017 alone (European Aggregates Association [UEPG], 2017). The resulting numerous artificial lakes (for simplicity henceforth referred to as 'gravel pit lakes') have become common elements in many cultural landscapes across the industrialized world (Oertli, 2018).

Lakes, including gravel pit lakes, provide many ecosystem services to humans. These include provisioning services, such as fish yield, as well as a range of cultural services, such as recreation (Meyerhoff, Klefoth, \& Arlinghaus, 2019; Venohr et al., 2018). Although the benefits of water-based recreation can be substantial, water-based activities can also impair the biodiversity of freshwater ecosystems (Venohr et al., 2018). For example, human activities can reduce littoral and riparian habitat quality, and thereby adversely affect associated taxa (Spyra \& Strzelec, 2019). Water-based recreation has also been found to have impacts on birds through fright responses to humans (Dear, Guay, Robinson, \& Weston, 2015), dogs (Randler, 2006), or pleasure boats (McFadden, Herrera, \& Navedo, 2017). Therefore, the management of gravel pit lakes and other artificial water bodies would benefit from the joint consideration of the well-being that aquatic recreation generates for humans and the possible damaging impacts on biodiversity from aquatic recreation.

Many gravel pit lakes located in central Europe are used for recreational fisheries (Matern et al., 2019; Zhao et al., 2016). In some regions of the world anglers are not only resource users but also managers of fish populations and habitats (Arlinghaus, Müller, Rapp, \& Wolter, 2017). This particularly applies to Germany, where organizations of anglers, usually angling clubs and associations, are leaseholders or owners of freshwater fishing rights, and in this position are also legally entitled to manage fish stocks (Arlinghaus, Müller, et al., 2017). This includes the right to stock fish, to manage littoral habitat, and to introduce access and harvest regulations (Arlinghaus, Müller, et al., 2017). As the stocking of fish is particularly prevalent in freshwater recreational fisheries management, key impacts of the presence of recreational fisheries and associated management activities can be expected at the fish stock and fish community levels (Matern et al., 2019; Zhao et al., 2016). Angler-induced changes typically elevate fish species richness through the release and introduction of large-bodied 'game' fishes of high fisheries interest (Matern et al., 2019; Zhao et al., 2016). In turn, the altered fish community may affect submerged macrophytes (e.g. by the introduction of benthivorous fish that uproot macrophytes; Bajer et al., 2016) and other taxa (e.g. birds, Cucherousset et al., 2012; amphibians, Hecnar \& M'Closkey, 1997; or invertebrates, Knorp \& Dorn, 2016), through predation. In addition, anglers may modify littoral habitats to create access to angling sites, thereby affecting the species richness of plants (O'Toole, Hanson, \& Cooke, 2009) and dragonflies (Müller et al., 2003), or affecting mobile taxa, such as birds, through direct contact and disturbances (Bell, Delany, Millett, \& Pollitt, 1997; Cryer, Linley, Ward, Stratford, \& Randerson, 1987). Indirectly, angler presence can also inadvertently kill non-targeted wildlife, such as through lost fishing gear that is ingested by birds or where birds become entangled (Franson et al., 2003; Sears, 1988). Therefore, anglers can be seen both as stewards of aquatic ecosystems (Granek et al., 2008) and as a potential threat to certain aquatic taxa, depending on the local angling intensity and other conditions (Reichholf, 1988).

In Germany, fisheries (including recreational angling) are regulated by fisheries laws specific to the Federal state, whereas the protection of species and habitats is regulated by Federal and state-specific nature conservation legislation. Conflicts with angler interests regularly occur when nature conservation authorities implement rules that partially or fully constrain access to water bodies to achieve conservation goals (Arlinghaus, 2005). Conservation-motivated constraints of angling or recreational fisheries management actions (e.g. stocking) are increasingly applied within artificial lake ecosystems through the implementation of national or international conservation law (e.g. the European Habitats Directive; Council of the European Communities, 1992). For example, in some regions of Germany recreational fisheries have been excluded from follow-up use of newly created gravel pit lakes during the process of licensing the sand or gravel extraction (Müller, 2012). Such bans of future angling use are often justified by the assumption that angling is particularly harmful for disturbance-sensitive taxa (e.g. waterfowl) or for habitats of special conservation concern (Müller, 2012; Reichholf, 1988).

In order to contribute to this continuing debate, the work presented here studied the taxonomic biodiversity associated with gravel pit lakes using a space-for-time substitution design, comparing lakes managed and used by recreational fisheries with lakes that do not 
experience recreational fisheries actions, and therefore lack angler impacts. The goal of the study was to examine the impact of recreational fisheries on the aquatic and riparian biodiversity detectable at typical gravel pit lakes in north-western Germany. The specific objective was to estimate the effect of recreational fisheries on species richness, faunal and floral composition, community diversity, and conservation value across a range of aquatic and riparian taxa (e.g. birds, amphibians, and dragonflies) that are protected by national and European conservation legislation. The absence of recreational fisheries in a given gravel pit lake does not mean that the ecosystem remains undisturbed from other recreational uses, such as swimming and walking. It was hypothesized, therefore, that the presence of recreational fisheries and associated management activities would, on average, not affect the species richness and conservation value of taxa that are not specifically targeted by anglers (Odonata, amphibians, submerged and riparian vegetation, waterfowl, and songbirds). This hypothesis was formulated as a statistical null hypothesis to be refuted by empirical data.

\section{2 | METHODS}

\subsection{Study area and lake selection}

This study was conducted in the Central Plain ecoregion of Lower Saxony in north-western Germany (Figure 1), where natural lentic waters are scarce. Of 35,048 ha of total standing waters in Lower Saxony, $73 \%$ by area and more than $99 \%$ by number are artificial lakes. These artificial water bodies consist mainly of ponds and small gravel pit lakes with a surface area of less than 10 ha (Cyrus et al., 2020).

Most gravel pit lakes in Lower Saxony, and in Germany as a whole, are managed for recreational fisheries by angler associations and clubs. These lakes are thus exposed to regular stocking with species of fisheries interest, and are subject to access and harvest rules, regular controls by fisheries inspectors, and fishing club activities, such as collecting litter and the cleaning and development of the littoral zone (Arlinghaus, Müller, et al., 2017). Similar activities are largely absent in gravel pit lakes not used for recreational fisheries, which are much rarer but still occur in Lower Saxony and elsewhere across Germany. For this study, a set of gravel pit lakes managed by recreational fisheries (defined as managed lakes) was selected and compared with another set of gravel pit lakes not experiencing any form of legal angling and recreational fishing-related management (defined as unmanaged lakes; Table 1).

Managed lakes were identified through a survey of all organized angling clubs in the Angler Association of Lower Saxony. Lakes were selected according to the following criteria: the lake was owned by a fishing club, was of small size (1-20 ha), and had not been dredged in the last 10 years ('old age'). This approach yielded 16 managed lakes for use as study sites spread across Lower Saxony in 10 angling clubs (Figure 1; Table 1). The angler density (number of anglers per unit water area) for these clubs ranged from 8 to 43 anglers per ha (mean \pm SE: $21 \pm 3.6$ anglers per ha). These angler densities correspond to averages known for German and Lower Saxonian angling clubs: $24 \pm 2.5$ and $22 \pm 10.8$ anglers per ha, respectively. All selected angler-managed lakes experienced regular angling activities and fisheries management actions, including the annual stocking of a range of fish species and regular shoreline development activities, such as mowing of angling sites and litter removal.

Gravel pits not managed by anglers were identified in close vicinity to the managed lakes, where possible (Figure 1). The number of unmanaged lakes in the state was much smaller than the number of managed lakes. Overall, 10 unmanaged lakes were identified, which were of similar age, size, and other environmental conditions to the managed lakes, but differed from the managed lakes in the absence of an angling club and any form of legal angling and fisheries management for at least 5 years before the onset of our study (Figure 1;
FIGURE 1 Map of study sites in Lower Saxony, Germany, together with the catchments (green, Ems; orange, Weser; magenta, Elbe; blue, small North Sea tributaries, SNST) and main rivers (dark blue: Ems, Weser, and Elbe)

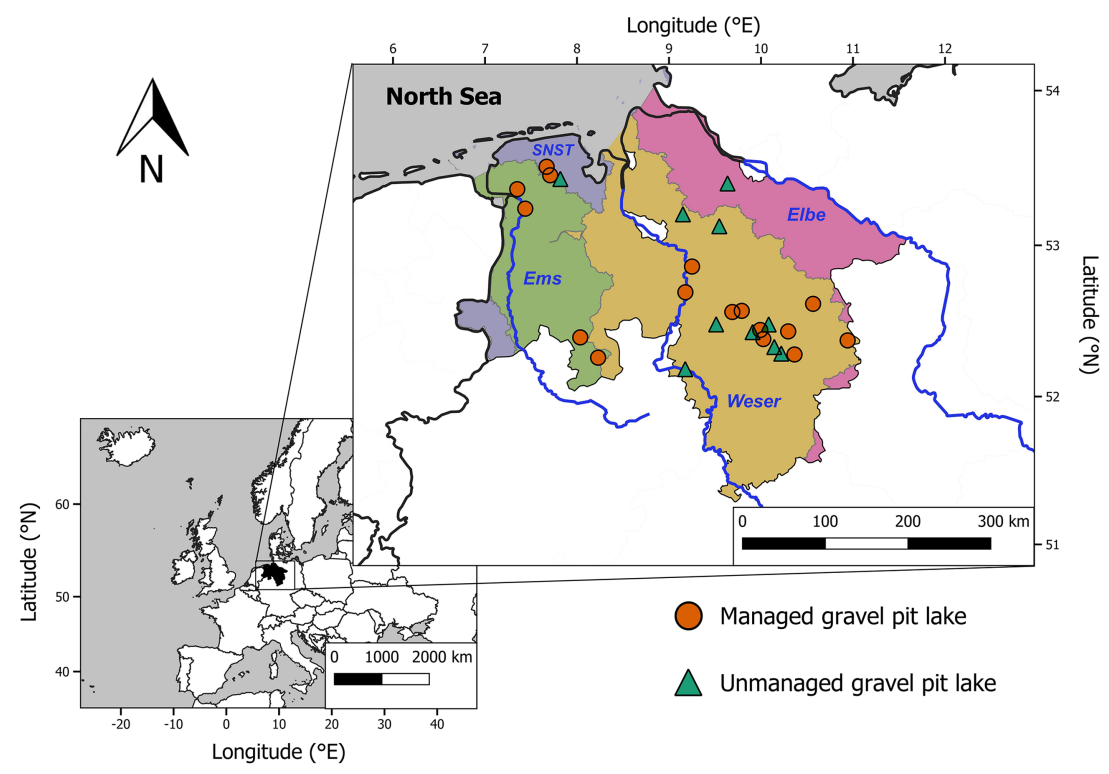



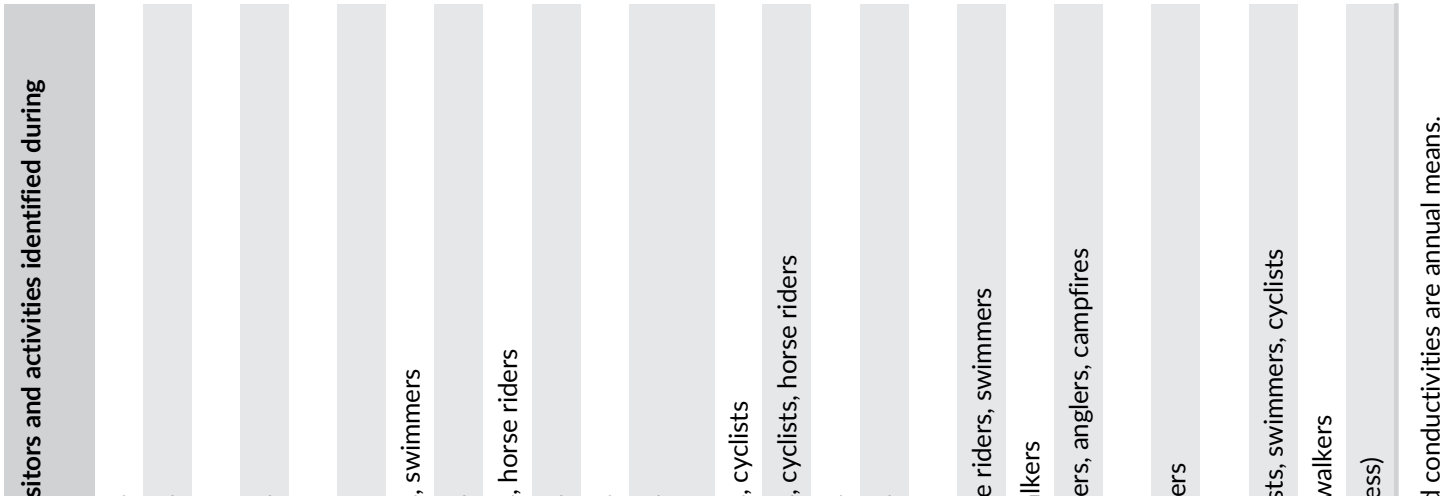

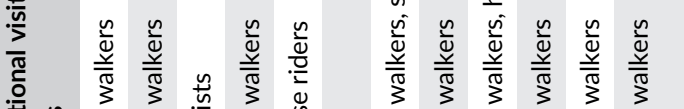

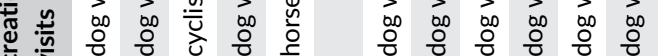

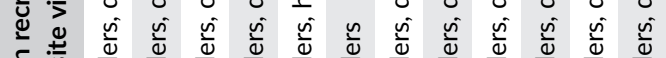

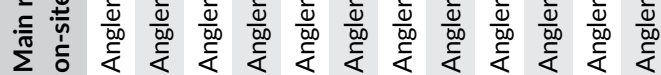

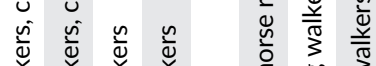

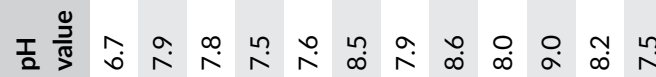

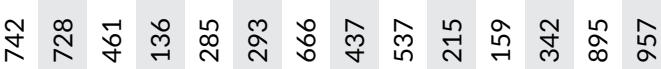

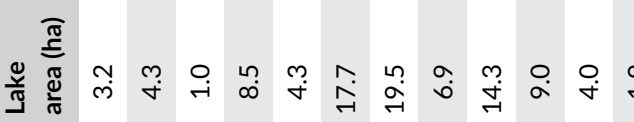

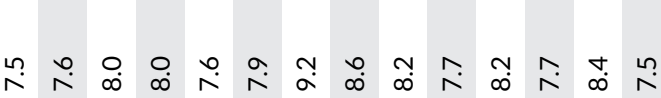

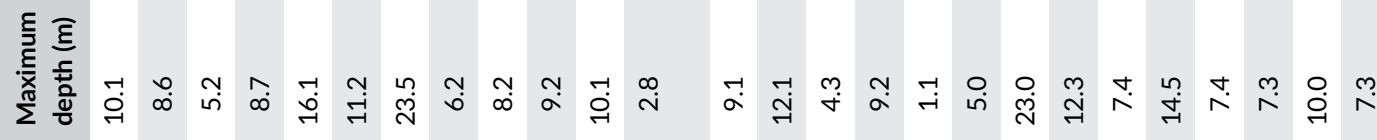

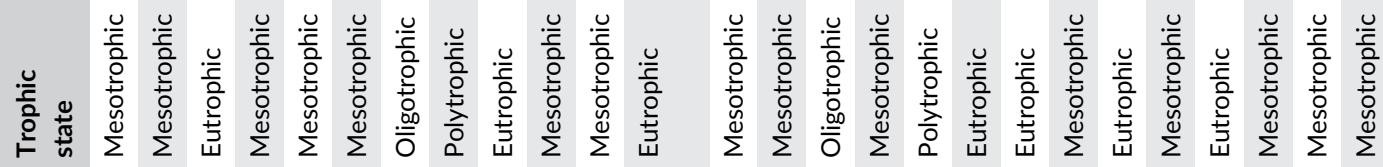

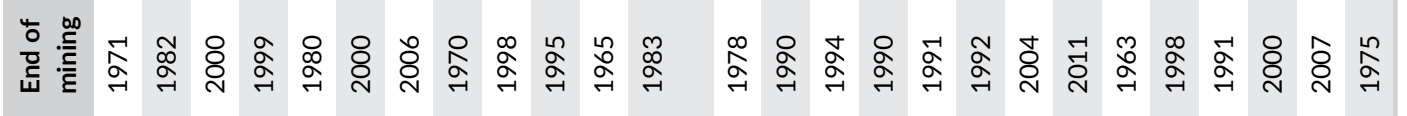

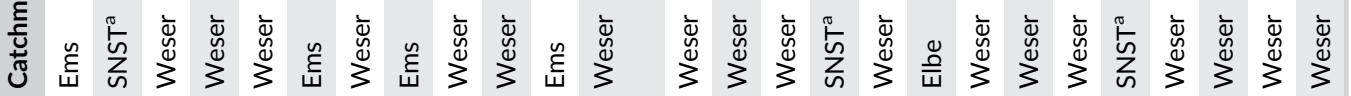

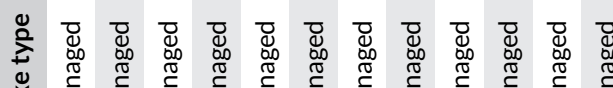

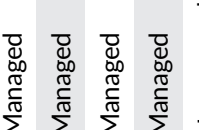


Table 1). Both lake types were accessible to non-angling recreation, as they were not fenced (with the exception of Linner See).

In a subset of the selected lakes, Matern et al. (2019) previously conducted fish faunistic surveys showing identical fish abundances and biomasses in both lakes types, but greater local fish species richness and significantly more abundant game fishes (particularly predators and large-bodied cyprinids such as carp, Cyprinus carpio) in managed lakes, compared with unmanaged lakes. These data show that the angler-managed lakes included in this study were indeed more intensively managed in terms of fish stocking and hosted a substantially different fish community. This finding was a relevant precondition of the study design in that managed and unmanaged lakes differed in traces left by fisheries management and fisheries use, both in their fish community composition and angler presence in the littoral zone.

Despite the attempt to select lakes with similar environments (e.g. age, surface area, and trophic state), a set of environmental variables was assessed and integrated within the statistical analyses to isolate the possible impact of recreational fisheries management on biodiversity, while controlling for other key environmental differences among lakes that might also affect the community composition of specific taxa (e.g. morphometry, land use, and habitat structure).

\subsection{Land use}

Several indicators of land use and spatial arrangement across catchments in Lower Saxony were assessed. Shortest-path distances of lakes to nearby cities, villages, lakes, canals, and rivers were calculated in GOOGLE MAPS 2017. Subsequently, a share of different land-use categories within $100 \mathrm{~m}$ around each lake (buffer zone) was calculated in QGIS 3.4.1 with GRASS 7.4.2 using ATKIS ${ }^{\circledR}$ land-use data with a $10 \mathrm{~m} \times 10 \mathrm{~m}$ grid scale (CGeoBasis-DE/BKG 2013; AdV - Working Committee of the Surveying Authorities of the States of the Federal Republic of Germany, 2006). The ATKIS ${ }^{\circledR}$ object categories were merged into seven land-use classes: (i) urban (including all anthropogenic infrastructures, such as buildings, streets, railroad tracks, etc.); (ii) agriculture (all arable land, such as fields and orchards, but not meadows or pastures); (iii) forest; (iv) wetland (e.g. swamps, fens, and peatlands); (v) excavation (e.g. open pit mines); (vi) water (e.g. lakes, rivers, and canals); and (vii) other (not fitting elsewhere, such as succession areas, grassland, boulder sites, etc.).

\section{3 | Recreational use intensity}

The lake-specific recreational use intensity was assessed by counting the type and number of recreational visitors during each site visit (with between six and nine visits per lake, see description of biodiversity sampling below). Metrics for the intensity of indirect use encompassed measures of accessibility and litter, which were assessed as follows: the length of all trails and pathways around each lake were measured with a measuring wheel ( $2 \mathrm{~m}$ circumference, $0.1 \%$ accuracy; Cross-country measuring wheel, model 12015001; NESTLE, Dornstetten, Germany). These variables were summed and normalized to shoreline length. Angling sites and other open spaces accessible to other recreational visitors (e.g. swimmers) along the shoreline were counted, and all litter encountered along paths and sites were counted and assigned to: (i) angling related (e.g. lead weight, nylon line, artificial bait remains); or (ii) other litter not directly related to angling (e.g. plastic packaging, beer bottles, cigarette butts). More intensively used lakes were expected to receive larger volumes of litter and be more easily accessible through paths and trampled sites, which could damage biodiversity.

\section{$2.4 \quad$ Age and morphology}

The age of each lake was assessed through records in the angling clubs and by interviewing owners of lakes and regional administrations or municipalities. Bathymetry and the size of each lake was mapped with a SIMRAD NSS7 evo2 echo sounder paired with a Lawrence TotalScan transducer mounted on a boat driven at 3-4 $\mathrm{km} \mathrm{h}^{-1}$ along transects spaced at 25-45 m, depending on lake size and depth. The data were processed using BioBase (Navico, Minneapolis, MN), and the post-processed data (depth and Global Positioning System (GPS) position per ping) were used to calculate depth contour maps using ordinary kriging with the GSTAT package in R 3.5.1 (Gräler, Pebesma, \& Heuvelink, 2016; R Core Team, 2013). Maximum depth and relative depth ratio (Damnjanović et al., 2018) were extracted from the contour maps. Shoreline length and lake area were estimated in QGIS 3.4.1 and used to calculate the shoreline development factor (SDF), which is the ratio of the lake shoreline length $(L)$ to the circumference of a circle with the same area $(A): S D F=\frac{L}{2 \sqrt{\pi A}}$.

\subsection{Water chemistry and nutrient levels}

During the spring overturn, epilimnic water samples were taken to analyse total phosphorus concentrations (TP), total organic carbon (TOC), ammonium and nitrate concentrations $\left(\mathrm{NH}_{4}, \mathrm{NO}_{3}\right)$, and chlorophyll $a$ (chl $a$; with three samples per lake) as a measure of algal biomass. TP was determined using the ammonium molybdate spectrophotometric method (EN ISO 6878, 2004; Murphy \& Riley, 1962), TOC was determined with a non-dispersive infrared detector (NDIR) after combustion (DIN EN 1484, 1997), ammonium and nitrate were assessed using the spectrometric continuous flow analysis (DIN EN ISO 13395, 1996; EN ISO 11732, 2005), and chl a was quantified using high-performance liquid chromatography (HPLC), where the phaeopigments (degradation products) were separated from intact chl $a$ and only the concentration of intact chl $a$ was measured (Mantoura \& Llewellyn, 1983; Wright, 1991). For chl $a$ the mean of three samples per lake was determined for each sampling. Also, during the spring overturn the conductivity and $\mathrm{pH}$ of each lake were measured in epilimnic water with a WTW Multi 350i sensor probe (WTW GmbH, Weilheim, Germany), and turbidity was assessed 
using a standard Secchi disc. For all variables, the mean values for 2 years (i.e. two samplings) were used in the analyses.

\subsection{Littoral and riparian habitat assessment}

Riparian structures and littoral dead wood were assessed using a plot design inspired by Kaufmann and Whittier (1997). Each plot consisted of a $15 \mathrm{~m} \times 4 \mathrm{~m}$ riparian subplot, a $1 \mathrm{~m} \times 4 \mathrm{~m}$ shoreline band, and a $4 \mathrm{~m}$-wide littoral transect, extending into the lake to a maximum of $10 \mathrm{~m}$ or a water depth of $3 \mathrm{~m}$. At each lake the position of the first plot was randomly selected and subsequent plots were placed every $100 \mathrm{~m}$ apart (or $150 \mathrm{~m}$ apart for larger lakes) along the shoreline until the lake was surrounded, resulting in between four and 20 plots per lake (depending on lake size). In each riparian subplot and shoreline band, all plant structures (e.g. trees, tall herbs, reeds) were assessed, following the protocol of Kaufmann and Whittier (1997): 0, absent; 1 , sparse ( $<10 \%$ coverage); 2 , moderate ( $10-39 \%$ coverage); 3 , dominant ( $40-75 \%$ coverage); and 4 , very dominant ( $>75 \%$ coverage). In each littoral transect all dead wood was counted and length and bulk diameters measured. In addition, the width and the height of each coarse woody structure was assessed, and each piece assigned to: (i) simple dead wood (bulk diameter of $<5 \mathrm{~cm}$ and length of $<50 \mathrm{~cm}$, no or very low complexity); or (ii) coarse woody structure (bulk diameter of $>5 \mathrm{~cm}$ and/or length of $>50 \mathrm{~cm}$, any degree of complexity), following the criteria of DeBoom and Wahl (2013). For each dead-wood structure the volume was calculated using the formula for a cylinder for simple dead wood and using the formula for an ellipsoid for any coarse woody structure.

\subsection{Riparian plant species}

All lakes were sampled for riparian plant species at four transects (one per cardinal direction) in May. Each transect was $100 \mathrm{~m}$ long and contained five evenly spaced (20 m distance) $1 \mathrm{~m}^{2}$ plots. Along the transects, trees (>2 $\mathrm{m}$ high) were identified following Spohn, Golte-Bechtle, and Spohn (2015) and counted. Within each sampling plot, riparian vascular plants $(<2 \mathrm{~m}$ high) were identified following the same key (Spohn et al., 2015) and their abundance assessed following Braun-Blanquet (1964). The regional species pool was estimated from the Red List of Lower Saxony (Garve, 2004), which includes a full species inventory, in combination with their expected occurrence according to habitat type and species' habitat preferences.

\section{8 | Submerged macrophytes}

All lakes were sampled for submerged macrophytes between late June and late August, following the sampling protocol of Schaumburg, Schranz, Stelzer, and Vogel (2014). Every lake was scuba-dived and snorkelled along transects set perpendicular to the shoreline from the bank (depth $=0 \mathrm{~m}$ ) to the middle of the lake until the deepest point of macrophyte growth was reached. The position of the first transect was randomly chosen and all other transects were spaced evenly along the shoreline at 80-150 m distances, depending on lake size, resulting in between four and 20 transects sampled per lake. Along each transect, the dominance of submerged macrophyte species in every depth stratum (0-1, $>1-2,>2-4,>4-6 \mathrm{~m}$ ) was visually estimated following the Kohler scale (Kohler, 1978). No macrophytes were found below a depth of $6 \mathrm{~m}$. Macrophytes were identified directly under water, or if this was not possible samples were taken and identified under a stereomicroscope following Van de Weyer and Schmitt (2011). Stonewort species were identified only to genus level (Chara and Nitella), and thus exact species numbers might be underestimated. Macrophyte dominance was transformed to percentage cover for each transect (Van der Maarel, 1979). The average cover per stratum was extrapolated to the total lake using the contour maps. The total macrophyte cover in the littoral zone was calculated using the extrapolated cover from strata between 0 and $3 \mathrm{~m}$ in depth. The regional species pool was estimated from the Red Lists of Lower Saxony, which include full species inventories, in combination with the expected species for gravel pit lakes following the list of plant species associations in Lower Saxony (Garve, 2004; Korsch, Doege, Raabe, \& van de Weyer, 2013; Preising et al., 1990).

\subsection{Amphibians}

Amphibians were sampled during the mating seasons (from March to May). Every lake was sampled twice: (i) during the day, with an inflatable boat driving slowly along the shore searching for adults, egg balls (frogs), and egg lines (toads); and (ii) after sunset, by foot around the lake searching for calling adults. Each observation (adult or eggs) was marked with a GPS (Oregon 600; Garmin, Olathe KS) and identified in the field or photographed for later identification, following Schlüpmann (2005). Numbers were recorded (adults) or estimated (eggs), assuming 700 to 1,500 eggs per egg ball (frogs) or 10,000 eggs per ( $100 \%$ covered) $\mathrm{m}^{2}$ of egg-line assemblages (toads). The egg numbers were calculated from pictures taken in the field and verified following Trochet et al. (2014). The regional species pool was estimated from the Red List of Lower Saxony, which includes a full species inventory, in combination with expected distributions (Podloucky \& Fischer, 2013).

\subsection{Odonata}

Dragonflies and damselflies were sampled once per lake between early- and mid-summer. At each lake, the whole shoreline was intensively searched during the middle of the day. Sitting or flushing adult individuals were caught with a hand net (butterfly net, $0.2 \mathrm{~mm}$ mesh size, bioform), identified using Lehmann and Nüss (2015), and released without being harmed. The regional 
species pool was estimated from the Red List of Lower Saxony, which includes a full species inventory, in combination with expected habitat preferences (Altmüller \& Clausnitzer, 2010; Lehmann \& Nüss, 2015).

\subsection{Waterfowl and songbirds}

Waterfowl were identified following Dierschke (2016) and counted at every visit (with between six and nine visits per lake). Songbirds were sampled once per lake between early- and mid-summer using pointcount sampling combined with a bioacoustics approach, which has also been used in other studies (Rempel, Hobson, Holborn, Van Wilgenburg, \& Elliott, 2005; Wilson, Barr, \& Zagorski, 2017). Twominute audio recordings (Handy Recorder H2, Surround 4-Channel setting, 44.1-kHz sampling frequency, 16-bit quantification; Zoom, Tokyo, Japan) were taken at sampling points placed $200 \mathrm{~m}$ apart around the whole lake, assuming that each sampling point covers a radius of $100 \mathrm{~m}$. Sampling points were marked with GPS. At each point all birds seen (or heard while not recording) were also noted when identified following Dierschke (2016). The audio recordings were analysed in the laboratory, and singing species were identified using reference audio samples (www.deutschevogelstimmen.de; www.vogelstimmen-wehr.de) and birdsong-identifying software (BIRDUP 2018 automatic birdsong recognition, developed by Jonathan Burn, https://play.google.com/store/apps/details?id= com.jb.birdlistener.birdup\%26hl=en_GB\%26gl=US). The regional species pools for waterfowl and songbirds were estimated from the Red List of Lower Saxony (Krüger \& Nipkow, 2015), which includes a full species inventory, in combination with their expected occurrence according to habitat type and preferences (Dierschke, 2016).

\subsection{2 | Diversity metrics}

The analysis focused on species presence-absence data to arrive at measures of taxonomic species richness, an aggregate index of species diversity. In addition, the Simpson diversity index (Pielou, 1969) was computed using relative abundance data by species to consider the dominance of certain species within each taxon-specific community. There was no consideration of whether a particular species detected actually recruits in a given gravel pit lake, only noting that the species was present, and assuming that the estimates represented a minimal estimate of local richness as rare species probably remained undetected. To weight rare and threatened species more heavily, the richness of threatened species was computed and an index of taxonspecific conservation value for the study region was estimated following Oertli et al. (2002). To that end, each species was ranked according to its threat status on the Red Lists of Lower Saxony (Altmüller \& Clausnitzer, 2010; Garve, 2004; Korsch et al., 2013; Krüger \& Nipkow, 2015; Podloucky \& Fischer, 2013). Species of Least Concern were ranked lowest: $c(0)=2^{0}=1$. All species classified with an increasing threat status category $r$ according to the regional Red List were weighted exponentially more strongly, as $c(r)=2^{r}$ (Table 2 ),
TAB LE 2 Ranking of Red List categories used for the calculation of conservation values

\begin{tabular}{lll} 
Red List categories of Lower Saxony & Rank $r$ & Weight c \\
1 - Critically Endangered & 4 & 16 \\
2 - Endangered or R - Rare & 3 & 8 \\
\hline 3 - Vulnerable or G - Indeterminate & 2 & 4 \\
V - Near Threatened & 1 & 2 \\
* - Least Concern or - Data Deficient & 0 & 1
\end{tabular}

following Oertli et al. (2002). For each lake, the final taxon-specific conservation value ( $\mathrm{CV}$ ) was calculated as the sum of all values for the observed species $s_{i}\left(s_{1}, s_{2}, s_{3}, \ldots, s_{n}\right)$ divided by the total number of species $(n)$ for a given taxon:

$$
C V=\frac{1}{n} \sum_{s_{i=1}}^{s_{n}} c\left(r_{s_{i}}\right)
$$

The conservation index value increases with more species of a given taxon being threatened or rare. A range of different allocations of threat status were tested to estimate the conservation value, also using national and European Red Lists. The results remained robust, however.

To test for differences in species composition across all lakes, the pooled species inventory by lake type (managed and unmanaged) was used, and the Sørensen index (Sørensen, 1948) as a measure of community similarity was calculated. The Sørensen index ranges from 0 (no species in common between the two lakes types) to 1 (all species the same), and is calculated as $2 a /(2 a+b+c)$, with $a$ being the number of shared species and $b$ and $c$ being the numbers of unique species to each lake type, respectively. As an indicator for whether species compositions are substantially (i.e. biologically meaningfully) different or not, so called 'faunal breaks' as well as 'floral breaks' were searched for. Following Matthews (1986), faunal or floral breaks among lake types were assumed to occur when the Sørensen index was $<0.5$.

\subsection{3 | Statistical analysis}

The impact of the presence of recreational fisheries management on aquatic and riparian biodiversity was tested in two steps.

First, differences in taxon-specific species richness, Simpson diversity index, richness of threatened species, conservation value, as well as key environmental variables between lake types (managed and unmanaged gravel pits) were assessed with univariate statistics. To that end, mean differences among lake types were tested using the Student's $t$-test (in cases of variance homogeneity) or Welch's F-test (in cases of variance heterogeneity) whenever the error term was normally distributed (Shapiro-Wilk-test). Otherwise, a MannWhitney $U$-test of median differences was used. $P$ values were Sidak-corrected for multiple comparisons (Šidák, 1967). Significance was assessed at $P<0.05$. 


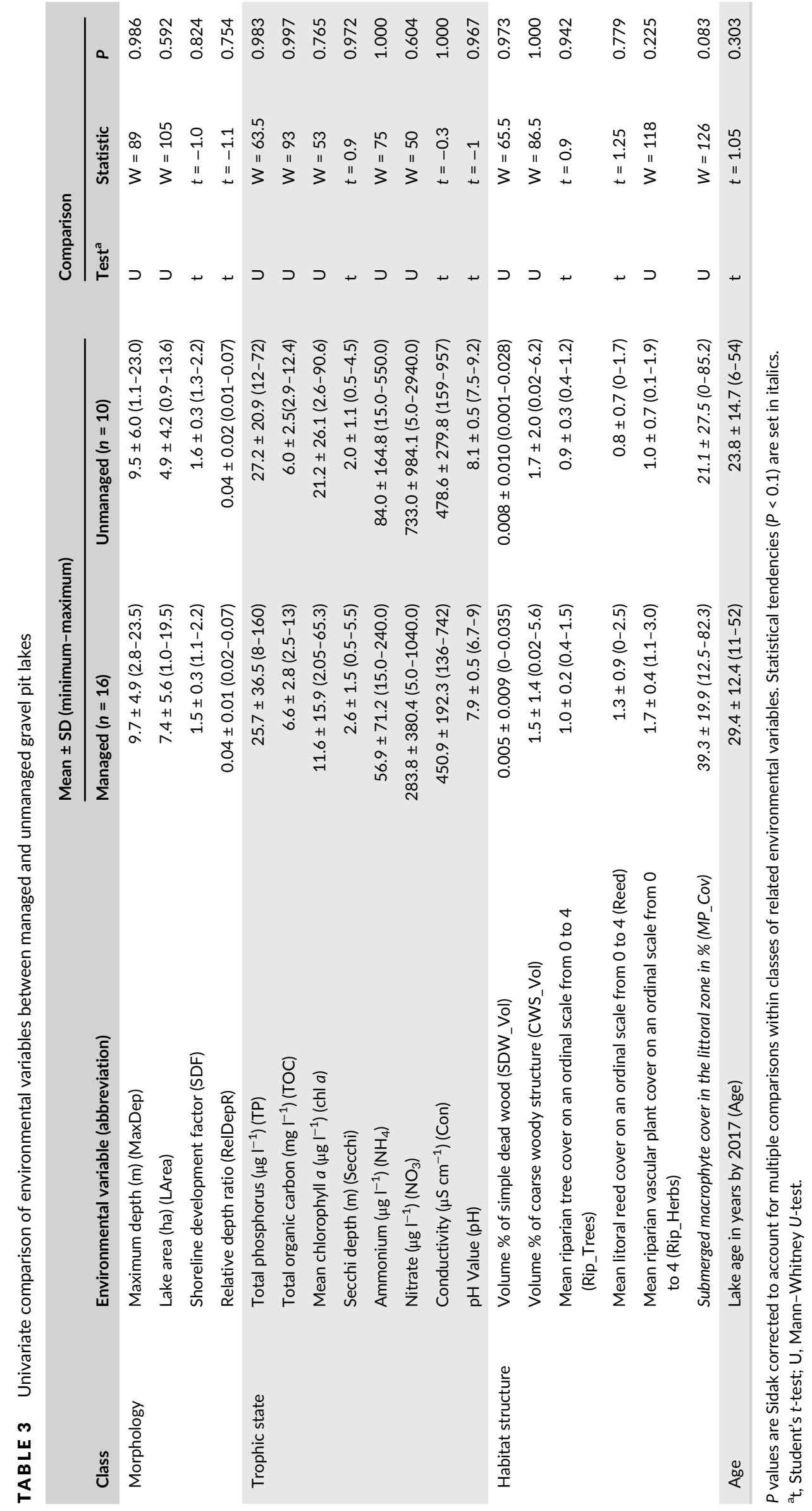


Second, the among-lake variation in species richness was modelled as a function of lake type and a set of lake-specific environmental descriptors. These analyses aimed to further isolate the impact of fisheries management and type of recreational use on species inventories across all taxa and lakes, in a joint model that included other predictor variables of the lake environment. To reduce the dimensionality of the environmental variables, principal component analyses (PCAs) without rotations were conducted on related classes of environmental variables (groups of environmental variables were structured into variables related to morphology, productivity, habitat structure, land use, and recreational use). Environmental variables forming principal components (PCs) were considered to be correlated, and their loadings were identified, axes interpreted, and the PC scores used as indicator variables. A multivariate redundancy analysis (RDA) was then conducted to examine whether recreational fisheries management explained variation in environmental variables or in species richness across multiple taxa in the multivariate space. In addition to lake type, all relevant environmental variables (e.g. trophic state, surface area/steepness, land use, riparian/littoral habitat structure, water chemistry), intensity of recreational use, gravel pit age, and catchment were included in the multivariate analysis of species richness. With the RDA, a forward selection process (Blanchet, Legendre, \& Borcard, 2008) was used to identify the environmental predictors that explained the most variance in species richness across different taxa and lakes, including management as a key variable of interest in this study. Using the variance inflation factor (VIF; Neter, Kutner, Nachtsheim, \& Wasserman, 1996), correlated environmental variables were removed before model building. All data were scaled and centred (transformed to $z$-values) before analysis. The degree of explanation was expressed using the adjusted coefficient of multiple determinations $\left(R^{2}\right.$ adj). Variables significantly explaining variation in richness across lakes were also assessed using analysis of variance (ANOVA) at a significance level of $P<0.05$. All calculations and analyses were carried out in R 3.5.1 using the VEGAN package (Oksanen et al., 2018; R Core Team, 2013).

\section{3 | RESULTS}

\section{1 | Description of lake types in relation to the environment}

The lakes studied were, on average, small (mean $\pm \mathrm{SD}$, area 6.5 \pm 5.2 ha, range 0.9-19.5 ha), shallow (maximum depth $9.6 \pm 5.2 \mathrm{~m}$, range 1.1-23.5 m), and mesotrophic (TP $26.3 \pm 30.9 \mu \mathrm{g} \mathrm{I} \mathrm{I}^{-1}$, range $8-160 \mu \mathrm{g} \mathrm{I}^{-1}$ ), with moderate visibility (Secchi depth $2.4 \pm 1.4 \mathrm{~m}$, range 0.5-5.5 m) (Table 3). The land use in a 100-m buffer around the lake was, on average, characterized by a low level of afforestation (mean $16 \pm 21 \%$, range $0-72.6 \%$ ) and a high level of agricultural land use (mean $27 \pm 22 \%$, range $2.4-79 \%$ ). On average, lakes were situated close both to human settlements (mean distance to the next village $618.3 \pm 533.4 \mathrm{~m}$, range $20-1810 \mathrm{~m}$ ) and to other water bodies (mean distance to next lake, river, or canal $55.8 \pm 84.7 \mathrm{~m}$, range 1-305 m). Gravel pit lakes were all in an advanced stage of succession, and were on average $27.3 \pm 13.3$ years old (range 6-54 years, see Tables S1-S4 for detailed lake-specific environmental variables). The study lakes belong to four different catchments (small North Sea tributaries and the catchments of the rivers Ems, Weser, and Elbe; Figure 1; Table 1).

\section{2 | Environmental characteristics of managed and unmanaged gravel pit lakes}

Both lake types did not differ statistically in age, size, trophic state, and land use (Table 3). A similar result was obtained in a multivariate RDA, which confirmed the absence of significant differences between managed and unmanaged lakes in 'classes of environmental variables' (i.e. PC scores, for details see Tables S5 and S6) representing morphology (an index of steepness and water body size; $R^{2}$ adj $=-0.005$, $F=0.86, P=0.470)$, trophic state $\left(R^{2}\right.$ adj $\left.=-0.006, F=0.86, P=0.544\right)$, proximity to other water bodies $\left(R^{2}\right.$ adj $\left.=-0.023, F=0.45, P=0.867\right)$, proximity to human presence $\left(R^{2}\right.$ adj $\left.=0.035, F=1.90, P=0.143\right)$, and land-use variables $\left(R_{\text {adj }}^{2}=0.033, F=1.85, P=0.135\right)$. However, in multivariate space the habitat structure differed significantly among managed and unmanaged lakes along the first PC axis (Dim 1), which represented a vegetation gradient below and above water (Figure 2).

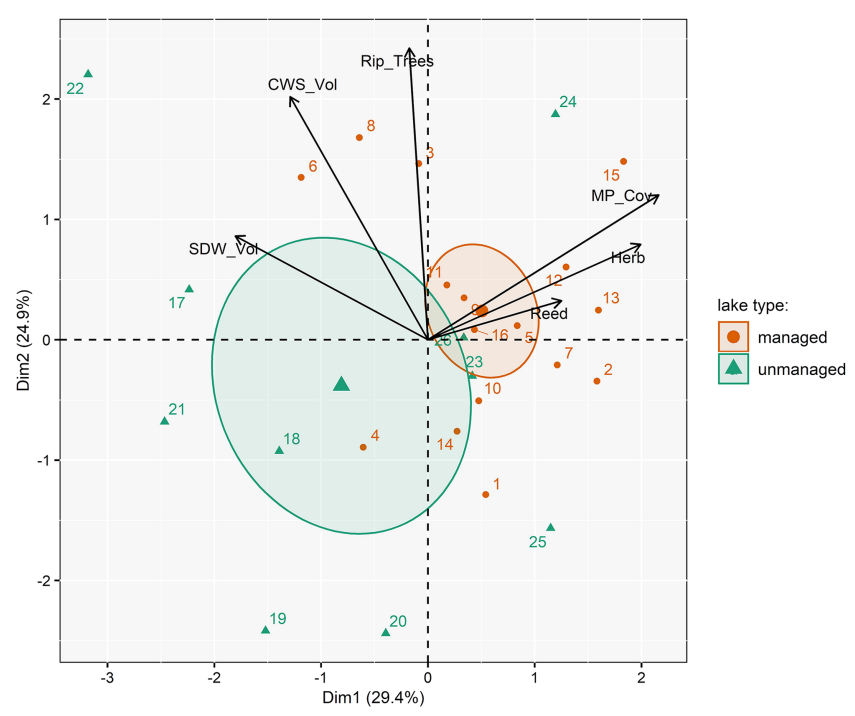

FIGURE 2 Principal component analysis (PCA) by classes of related environmental variables visualized for habitat structure (SDW_Vol, volume \% of simple dead wood; CWS_Vol, volume \% of coarse woody structure; Rip_Trees, mean riparian tree cover; Herb, mean riparian vascular plants cover; Reed, mean litoral reed cover; MP_Cov, submerged macrophyte cover in the littoral zone; Table 3). Percentages in brackets show the proportional variance explained by each axis, respectively. Numbers reflect the different lakes (Table 1). The centroids of lake types are plotted as supplementary variables that did not influence the ordination. The $95 \%$ confidence levels around centroids are plotted to visualize differences between lake types 

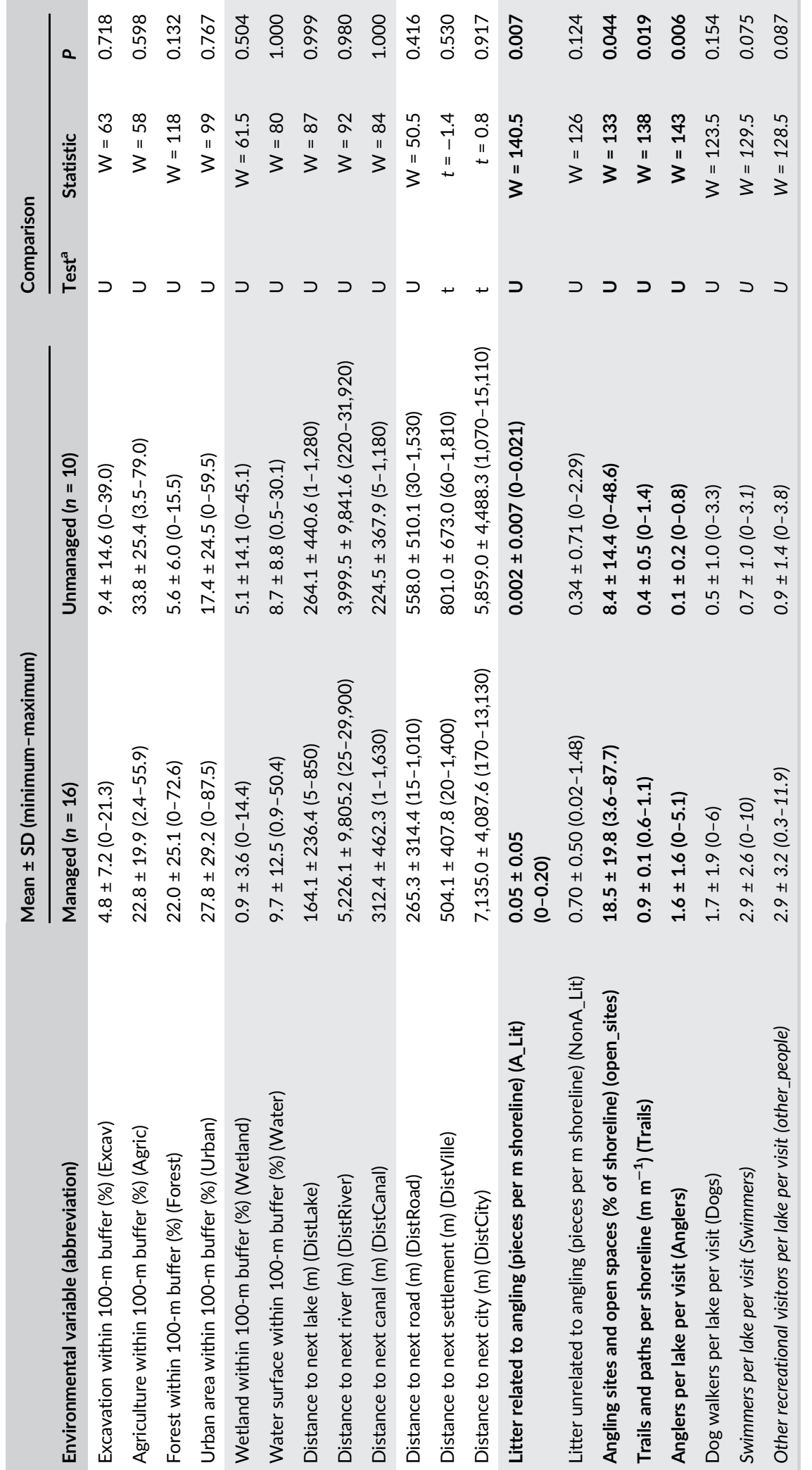

$\frac{\substack{\frac{\pi}{2} \\ \frac{\pi}{5}}}{\frac{\pi}{5}}$

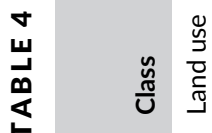

$\frac{\bar{d}}{3}$

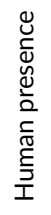

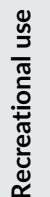

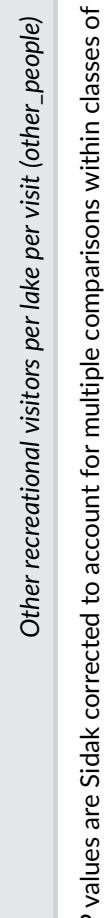

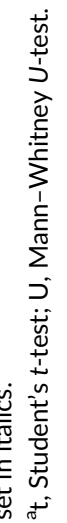


Along this axis, managed lakes were found to be more vegetated than unmanaged lakes in both the riparian and the littoral zones $\left(R_{\text {adj }}^{2}=0.056, F=2.48, P=0.022\right)$.

\section{3 | Recreational uses of managed and unmanaged lakes}

The two lake types differed strongly in their intensity of recreational use, particularly in relation to the observed angling intensity. Managed lakes revealed, on average, significantly higher angling use intensity, indexed by a diverse set of variables such as angling litter density, extension of open sites, paths and trails, and the number of anglers observed (Table 4). By contrast, the average recreational use intensity of managed and unmanaged lakes by non-angling recreational visitors (e.g. swimmers) did not differ statistically when analysed by univariate statistics on a variable-by-variable basis (Table 4). When all indicator variables of recreational use, including both angling and non-angling variables, were combined in a multivariate RDA analysis as a function of lake type, however, the managed lakes were separated from the unmanaged lakes along PC axis 1. This axis represented differences in recreational use intensity, both by anglers and other recreational visitors (particularly swimmers) and by the extension of trails and paths $\left(R^{2}{ }_{\text {adj }}=0.16, F=5.76, P<0.001\right.$; Figure 3$)$. Note that there was no

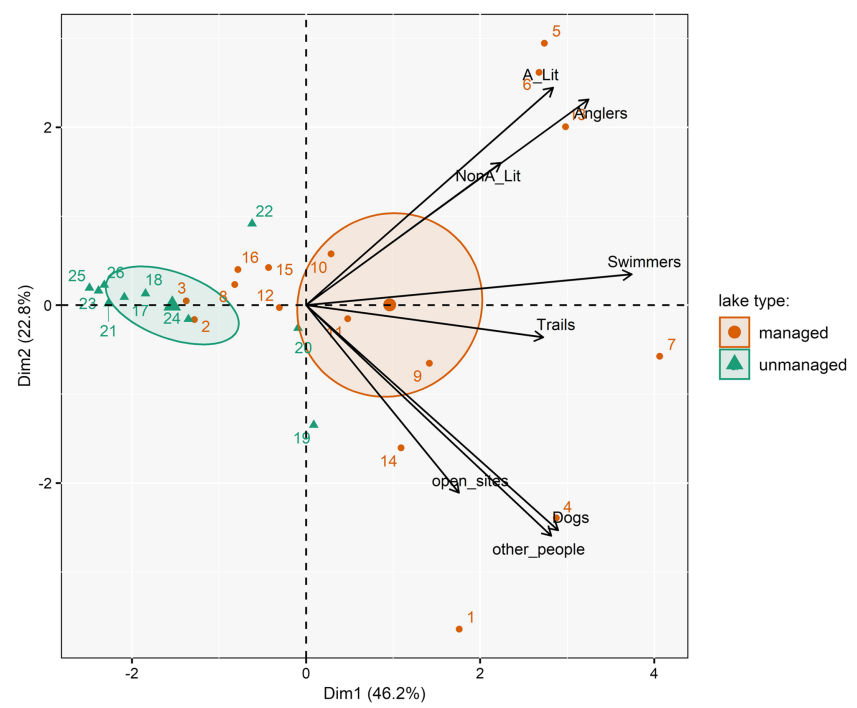

FIGURE 3 Principal component analysis (PCA) by classes of related environmental variables visualized for recreational use intensity (A_Lit, litter related to angling; NonA_Lit, litter unrelated to angling; open_sites, angling sites and open spaces; Trails, trails and paths per shoreline; Anglers, number per visit; Dogs, dog walkers per visit; Swimmers, number per visit; other_people, other recreational visitors per visit; Table 4). Percentages in brackets show the proportional variance explained by each axis, respectively. Numbers reflect the different lakes (Table 1). The centroids of lake types are plotted as supplementary variables that did not influence the ordination. The $95 \%$ confidence levels around centroids are plotted to visualize differences between lake types differentiation among lake types along the second PC axis of recreational variables (Figure 3), representing shoreline (in) accessibility.

\subsection{Species diversity and taxon-specific conservation value in managed and unmanaged gravel pit lakes}

In total, 41 submerged macrophyte species were detected, 191 riparian vascular plant, 44 tree, three amphibian, 33 Odonata, 36 songbird, and 34 waterfowl species. This species inventory represented a substantial proportion of the regional species pool of trees $(59 \%)$, Odonata (56\%), and waterfowl (45\%). By contrast, only one-third or less of the regional species pool of amphibians (38\%), songbirds (33\%), submerged macrophytes (33\%), and vascular plants (12\%) were detected. Only a few species non-native to Lower Saxony or Germany were found: four submerged macrophyte species (e.g. Elodea nuttallii, which is invasive), four riparian tree species, two waterfowl species (e.g. Alopochen aegyptiaca, which is invasive), one riparian vascular plant species, and one dragonfly species.

Based on the pooled species inventories (gamma diversity), unique species (i.e. species present in only one lake or only one lake type) were found in all taxonomic groups except for amphibians (Table 5). Managed lakes hosted more unique species within most taxonomic groups than unmanaged lakes, whereas unmanaged lakes had more unique Odonata. No faunal or floral breaks were detected between managed and unmanaged lakes using the Sørensen index (all indices $\geq 0.5$; Table 5). The average taxonspecific species richness (alpha-diversity), the Simpson diversity index, the average number of threatened species, and the average taxon-specific conservation value were statistically similar in managed and unmanaged lakes across all taxonomic groups when analysed using univariate statistics (Table 6).

TABLE 5 Overview about unique species of different taxa found at managed and unmanaged gravel pits in Lower Saxony, Germany

\begin{tabular}{|c|c|c|c|}
\hline \multirow[b]{2}{*}{ Taxon } & \multicolumn{2}{|c|}{$\begin{array}{l}\text { Species number found } \\
\text { only in: }\end{array}$} & \multirow[b]{2}{*}{$\begin{array}{l}\text { Sørensen index } \\
\text { (similarity) }\end{array}$} \\
\hline & $\begin{array}{l}\text { managed } \\
\text { lakes }\end{array}$ & $\begin{array}{l}\text { unmanaged } \\
\text { lakes }\end{array}$ & \\
\hline $\begin{array}{l}\text { Submerged } \\
\text { macrophytes }\end{array}$ & $15(13)$ & $10(9)$ & 0.58 \\
\hline $\begin{array}{l}\text { Riparian } \\
\text { vascular } \\
\text { plants }\end{array}$ & $55(35)$ & $31(23)$ & 0.73 \\
\hline Riparian trees & $6(4)$ & $5(4)$ & 0.86 \\
\hline Amphibians & $0(0)$ & $0(0)$ & 1.00 \\
\hline Odonata & $5(3)$ & $8(4)$ & 0.76 \\
\hline Songbirds & $9(7)$ & $6(5)$ & 0.74 \\
\hline Waterfowl & $10(3)$ & $6(3)$ & 0.69 \\
\hline
\end{tabular}

The numbers in brackets refer to single-lake observations, i.e. the number of species found at only one lake each. 
TAB LE 6 Univariate comparison of species richness, Simpson index, threatened species, and taxon-specific conservation values in managed and unmanaged gravel pit lakes

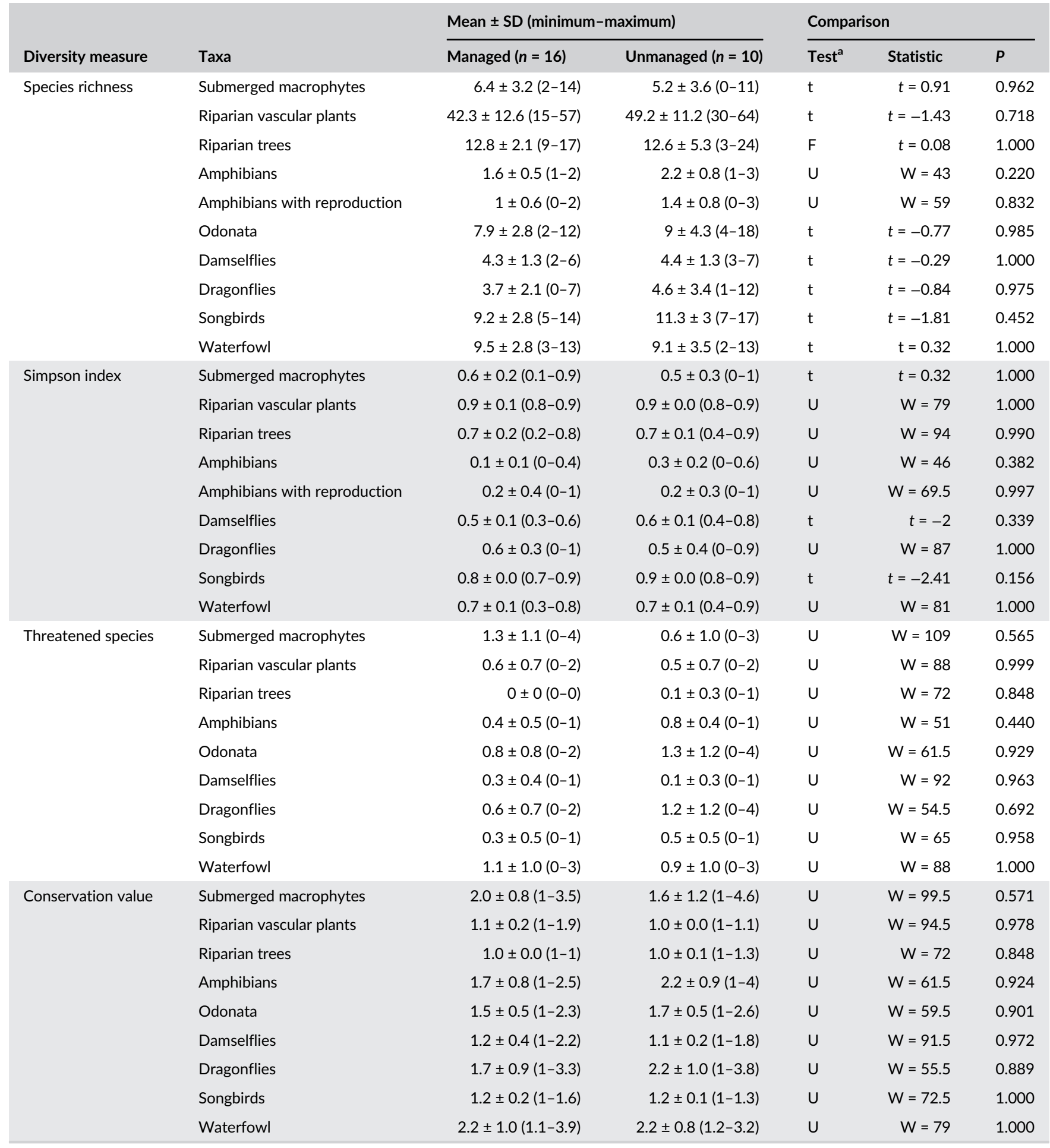

${ }^{\mathrm{a}} \mathrm{F}$, Welch's F-test; t, Student's t-test; U, Mann-Whitney U-test.

\section{5 | Environmental correlates of among-lake variation in species richness}

Across lakes, the species richness of amphibians, Odonata, songbirds, and riparian vascular plants covaried along the first axis (Figure 4), collectively representing riparian diversity (for full PCA results, see Table S8). The second PCA axis mainly represented submerged macrophytes (Figure 4). The third axis was related to the diversity of riparian tree species and the fourth axis was mainly related to waterfowl diversity (Figure 5). Therefore, lakes offering high riparian species richness were not necessarily rich in the biodiversity of submerged macrophytes, waterfowl, or trees. The RDA 


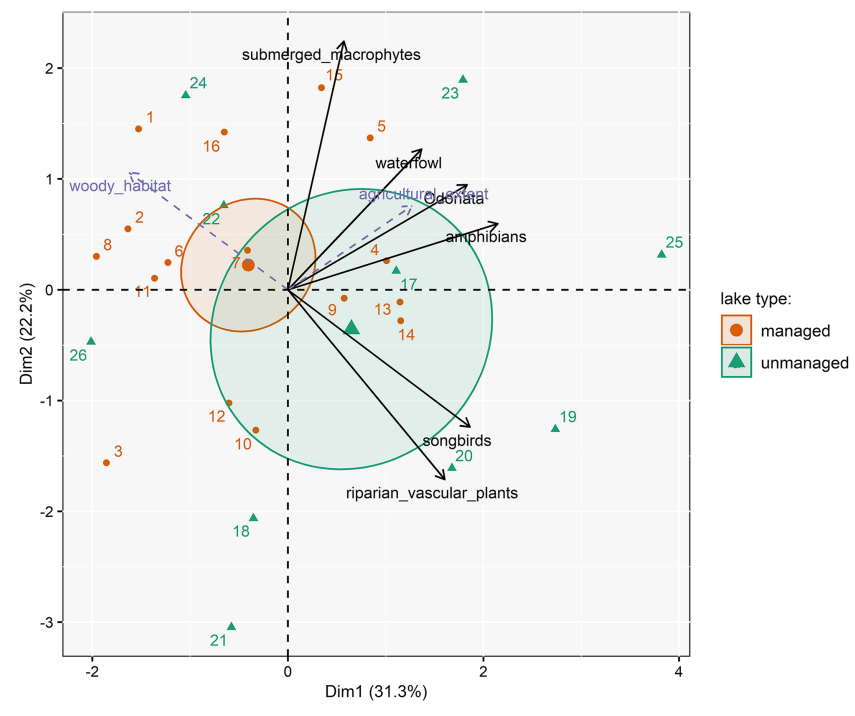

FIGURE 4 Principal component analysis (PCA) of species richness plotted for the first two axes (only relevant, i.e. highly contributing, variables are shown). Percentages in brackets show the proportional variance explained by each axis, respectively. Numbers reflect the different lakes (Table 1). The centroids of lake types and the explanatory variables from redundancy analysis (RDA, dashed purple lines, with only the important ones for Dim 1 and Dim 2 shown) are plotted as supplementary variables so as not to influence the ordination. The $95 \%$ confidence levels around centroids are plotted to visualize differences between lake types

analysis used to explain the among-lake variation in species richness as a function of lake type alone revealed no influence of this factor on among-lake richness across several taxa (RDA, $R^{2}{ }_{\text {adj }}=0.028$, $F=1.73, P=0.114)$.

All environmental variables subsumed by PC scores into environmental predictors and lake age had acceptable inflation factors (VIF < 5, maximum 4.98; Table S7) and were used together with catchment association and lake type in the full RDA analysis to explain among-lake species richness jointly across all taxa. The RDA-based forward model selection retained a few environmental variables as key correlates of the species richness of multiple taxa across lakes, but lake type was dropped from the best model (Table 7). Therefore, among-lake variation in species richness across several aquatic and riparian taxa was solely explained by environmental factors unrelated to either lake type or recreation-related variables. Specifically, the coverage of woody habitat along the littoral was negatively correlated with riparian species richness and positively correlated with tree diversity along the first axis in Figure 4. The extent of agricultural land use (also representing more rural conditions; Table S6) was positively associated with riparian species richness (Figure 4). Lake steepness (also representing small lake size and low shoreline development factor; Table S5) was negatively correlated with waterfowl species richness (Figure 5). All other environmental variables, including lake age and catchment, were not significant (Table 7). The best model explained $36 \%$ of the total variance in the multivariate species richness. In this model, neither lake type nor any of the recreational use

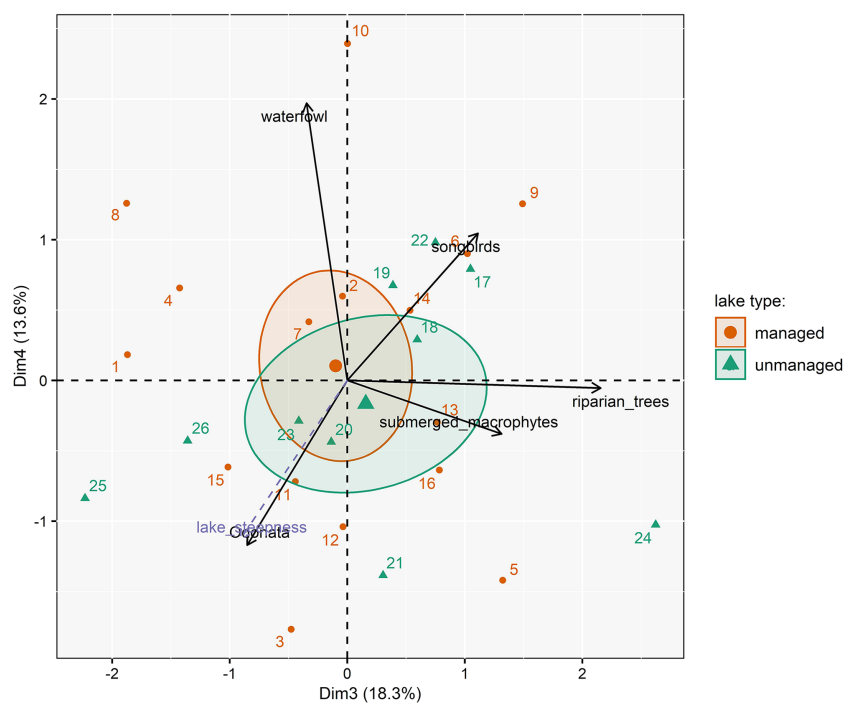

FIGURE 5 Principal component analysis (PCA) of species richness plotted for the third and fourth axis (only relevant, i.e. highly contributing, variables are shown). Percentages in brackets show the proportional variance explained by each axis, respectively. Numbers reflect the different lakes (Table 1 ). The centroids of lake types and the explanatory variables from redundancy analysis (RDA, dashed purple lines, with only the important ones for Dim 3 and Dim 4 shown) are plotted as supplementary variables so as not to influence the ordination. The $95 \%$ confidence levels around centroids are plotted to visualize differences between lake types

variables explained variation in species richness of a range of aquatic and riparian taxa among lakes.

\section{DISCUSSION}

In line with initial expectations, no differences in species richness, Simpson diversity, and conservation value were found across all examined taxa between managed and unmanaged gravel pit lakes, and a similar species pool was found to be present in both lake types. Collectively, this study did not reveal that recreational fisheries management (through impacts on fish communities) or the presence of anglers (through disturbance effects on shoreline habitat and wildlife or lethal impacts through lost fishing gear) significantly constrains the development of diverse communities of amphibians, birds, submerged macrophytes, terrestrial plants, and Odonata, relative to those expected at lakes that are not managed for recreational fisheries. Instead, the best predictors of the variation in species richness among lakes were found to be related to land-use variables, the extent of woody habitat on the lake shores, and the lake morphology (surface area and steepness). Therefore, this study suggests that for the taxonomic groups and lake types that were examined, broader environmental factors and land use, and not the presence of recreational fisheries, and its management of fish stocks and littoral zones, shape the taxonomic diversity of plants, birds, amphibians, and dragonflies. 
TAB LE 7 Analysis of variance (ANOVA) results of forward selection of redundancy analysis models explaining species richness across taxa

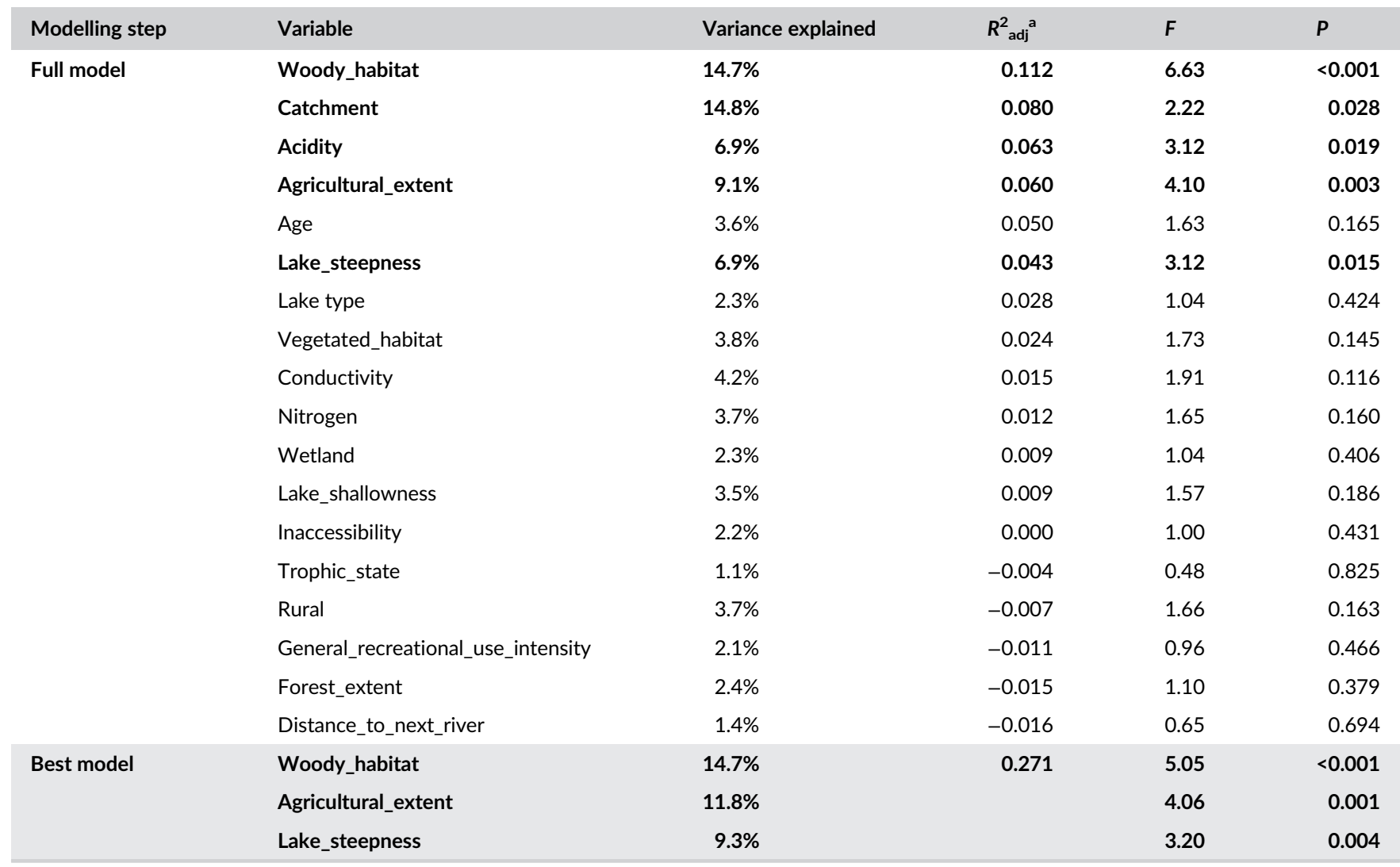

Variables are ordered by their $R^{2}$ adj value. Statistically significant results $(P<0.05)$ are shown in bold.

${ }^{\mathrm{a}} R^{2}$ adj values are shown for single-variable models and the best model. The full model has an $R^{2}$ adj value of 0.445 .

\section{1 | Biodiversity potential of gravel pit lakes}

Gravel pit lakes in Lower Saxony, Germany, were found to host substantial species diversity and a high proportion of the regional species pools of aquatic and riparian taxa, especially trees, Odonata, and waterfowl. This finding supports related work in other areas of Europe (Damnjanović et al., 2018; Holtmann, Juchem, Brüggeshemke, Möhlmeyer, \& Fartmann, 2018; Oertli, 2018; Spyra \& Strzelec, 2019), yet only small proportions of the regional species pools were detected for vascular plant species, submerged macrophytes, songbirds, and amphibians. In particular, amphibians are considered very sensitive to predation from fish (Hecnar \& M'Closkey, 1997), and none of the study lakes were free of fish (Matern et al., 2019). Many amphibian species depend on shallow water and develop best in small, temporary water bodies (Shulse, Semlitsch, Trauth, \& Williams, 2010). The gravel pits in this study also had relatively steep slopes, with small areas of littoral zone, were disconnected from rivers, were located in agricultural landscapes, and were close to anthropogenic infrastructure. All of these factors are unfavourable for amphibian diversity and can explain the low species richness detected for this taxonomic group (Shulse et al., 2010). Importantly, the results of this study indicate that management by recreational fisheries and the substantially different fish communities in managed and unmanaged lakes can be excluded as an additional stressor.

\section{2 | Environmental differences between managed and unmanaged lakes}

The gravel pit lakes studied were similar in the majority of the environmental factors examined (including age), except for the cover of submerged macrophytes, which was more prevalent in managed gravel pit lakes compared with unmanaged lakes. Submerged macrophytes have been reported to be strongly affected by stocking benthivorous fishes, such as the common carp (Bajer et al., 2016; Miller \& Crowl, 2006). In a subset of the same gravel pit lakes presented here, however, Matern et al. (2019) found a similar biomass of fishes in managed and unmanaged lakes, with carp and bream (Abramis brama) being present in both lake types. Owing to the sampling gear used by Matern et al. (2019), the authors are likely to have underestimated the abundance and biomass of the common carp and other large benthivorous fish (Ravn et al., 2019). Although no data are available on the absolute biomass of carp or other species in the study lakes, the fact that submerged macrophytes were more diverse and more developed in the angler-managed lakes suggests that the coexistence of carp and other game fish with a species-rich submerged macrophyte community, including threatened stonewort species (Chara sp. and Nitella sp.), is possible. This is contrary to expectations expressed elsewhere that managing lakes with benthivorous fish necessarily harms submerged macrophytes (Van de Weyer, Meis, \& 
Krautkrämer, 2015). Instead, the more developed submerged macrophytes in the managed lakes studied here suggests that critical biomass thresholds for benthivorous fish, after which macrophytes often vanish or strongly decline (approx. $100 \mathrm{~kg} \mathrm{ha}^{-1}$; Vilizzi, Tarkan, \& Copp, 2015), might not have been reached. Alternatively, the transferability of the typical mesocosm studies that have reported substantial impacts of carp on macrophytes to occur after reaching approximately $100 \mathrm{~kg} \mathrm{ha}^{-1}$ may not hold under conditions found in the wild (Arlinghaus, Hühn, et al., 2017).

Lake shorelines managed by anglers were previously reported to be heavily modified to accommodate angling sites and provide access for anglers (O'Toole et al., 2009). At the same time, crowding is a severe constraint that reduces angler satisfaction (Beardmore, Hunt, Haider, Dorow, \& Arlinghaus, 2015). Although improved accessibility in angler-managed lakes was supported in this study, the amount of aquatic and riparian vegetation was significantly greater in anglermanaged systems compared with unmanaged lakes. This indicates that maintaining the accessibility of lake shores for anglers does not necessarily mean degraded riparian or littoral habitat quality. Anglers have an interest in maintaining their access to lakes to be able to fish, but there is also an interest in developing suitable habitats for fish (Meyerhoff et al., 2019) and maintaining sites that promise solitude during the experience (Beardmore et al., 2015), which may also support biodiversity indirectly. We speculate that the regular shoreline development activities by anglers and angling clubs to maintain access to angling sites may create 'disturbances' (O'Toole et al., 2009) that regularly interrupt the succession of tree stands, thereby reducing the shading effects in the littoral zone (Monk \& Gabrielson, 1985) and promoting the growth of submerged macrophytes (Holtmann, Kerler, Wolfgart, Schmidt, \& Fartmann, 2019). The littoral zone is the most productive habitat of lakes (Winfield, 2004), and most fish species depend on submerged macrophytes and other structures for spawning, foraging, and refuge (Lewin, Mehner, Ritterbusch, \& Brämick, 2014). Therefore, although anglers regularly engage in shoreline development activities and angling site maintenance, the data from this study suggest that they do so in a way that maintains or even fosters aquatic and riparian vegetation.

\subsection{Differences in recreational use of managed and unmanaged lakes}

Managed lakes were found to have more developed tracks, paths, parking places, and other facilities that attract anglers and other recreational visitors. Thus, angler-managed lakes were generally more accessible to water-based recreational visitors, although these differences were not always statistically significant between the two lake types for recreational uses other than angling. Importantly, despite managed lakes receiving regular fisheries management activities, such as stocking and angler use, both lake type and the index of general recreational use intensity were not related to species richness across multiple taxa and lakes. Thus, for the diversity metrics and the taxa examined (amphibians, birds, Odonata, vegetation), this study does not suggest that the use of gravel pits by recreational fisheries significantly constrains the development of aquatic and riparian biodiversity across a range of taxa. Clearly, species-specific effects on disturbance-sensitive species may still occur (e.g. selected bird species; Knight, Anderson, \& Marr, 1991), which the combined metrics of taxonomic richness or the Simpson diversity index might have been too insensitive to detect. Further work on community differences between managed and unmanaged lakes is warranted.

\section{4 | Differences in biodiversity among managed and unmanaged lakes}

Across all taxa examined, no statistical differences were found in species richness, number of threatened species, conservation value, and Simpson diversity index between managed and unmanaged lakes. This result was unexpected. The management of recreational fisheries can affect aquatic and riparian biodiversity through various pathways: (i) through supporting and enhancing fish stocks that exert predation pressure (e.g. on tadpoles and Odonata larvae; Hecnar \& M'Closkey, 1997; Knorp \& Dorn, 2016); (ii) through indirect fish-based effects (e.g. uprooting macrophytes through benthivorous feeding; Bajer et al., 2016); (iii) through the direct removal or damage of submerged and terrestrial plants during angling activities (O'Toole et al., 2009), which may have knock-on effects on dragonflies (Müller et al., 2003); and (iv) through activity-based disturbance effects or lethal impacts through lost fishing sinkers, in particular for birds (Cryer et al., 1987; Sears, 1988). This study design was not tailored towards directly measuring disturbance effects on particular species; instead, it was designed to examine a range of taxonomic richness indices in aggregate for communities present at gravel pit lakes used by recreational fisheries compared with ecologically similar lakes that are not used by recreational fisheries. When judged against these aggregate biodiversity metrics, the study presented here does not support the idea that recreational fisheries management and angler presence have major impacts that modify species inventories to such a degree that they strongly depart from the biodiversity expected at unmanaged lakes without anglers. Previous work has reported relevant reductions in bird biodiversity from lakes exposed to human disturbances caused by recreation, including angling (Bell et al., 1997); however, similar species richness and conservation value, both of waterfowl and riparian songbirds, in managed and unmanaged lakes were found in the present work. This does not exclude the possibility, for example, that the breeding success of specific disturbance-sensitive taxa might have been impaired in angler-managed lakes (Park, Park, Sung, \& Park, 2006; Reichholf, 1988), but if such effects were present they were not strong enough to alter species richness (not to be confused with species identity) substantially. Overall, against the metrics chosen, the findings supported the initial hypothesis of no impacts from recreational fishing on non-targeted taxa in gravel pits situated in agricultural landscapes. 


\subsection{Environmental determinants of aquatic and riparian biodiversity in gravel pit lakes}

The species richness of different taxa did not vary uniformly among lakes, in contrast to the findings from a study of managed shallow ponds conducted by Lemmens et al. (2013). While examining strictly aquatic taxa (zooplankton, submerged and emergent aquatic macrophytes, benthic invertebrates), Lemmens et al. (2013) recorded uniform responses in species richness across taxa and ponds in their study. The much broader trophic and habitat requirements of aquatic and riparian taxa examined here resulted in significantly more variable biotic responses. For example, lakes rich in riparian biodiversity were not necessarily rich in submerged macrophytes and waterfowl biodiversity. The reason was that the aquatic and riparian biodiversity responded to many variables beyond those measured within the lake. The multivariate analyses showed that variation in species richness across multiple taxa was driven by structural variables such as habitat quality, lake morphometry (surface area and steepness) and land use in a buffer zone around the lake, but not by recreational use intensity or the presence of recreational fisheries management activities. Thus, environmental factors unrelated to recreational fishing seem to overwhelm any specific impacts of angling, at least for the taxonomic diversity metrics and the taxa examined here.

Mosaics of different habitats (reeds, overhanging trees, etc.) along the shoreline support species richness and diversity for most taxa (Kaufmann, Hughes, Whittier, Bryce, \& Paulsen, 2014), and the presence of endangered biota increase the recreational value of gravel pit lakes as perceived by anglers (Meyerhoff et al., 2019). Extended woody habitat both in water and particularly in the riparian zone was correlated with increased tree diversity, but reduced riparian species richness of vascular plants, amphibians, Odonata, and songbirds. This might be explained by the shading effect of trees on non-woody vegetation (Monk \& Gabrielson, 1985). Odonata, songbirds, and amphibian species benefited from more vegetated littoral habitats, in agreement with previous work (Paracuellos, 2006; Remsburg \& Turner, 2009; Shulse et al., 2010). The species richness of waterfowl was strongly governed by lake surface area and steepness of the littoral zone, with larger and shallower lakes having a higher waterfowl species richness, confirming earlier findings reported by Paszkowski and Tonn (2000). The three dominant waterfowl species (occurring on $85 \%$ or more of the sampled lakes) were either omnivorous (mallard, Anas platyrhynchos) or herbivorous-invertivorous (common coot, Fulica atra; tufted duck, Aythya fuligula). In addition, $77 \%$ of the lakes were used by the grey goose (Anser anser), which feeds on terrestrial plants. Thus, it can be concluded that the dominant waterfowl detected at the lakes studied benefit from submerged macrophytes or riparian plants, which are both found to be more abundant at managed lakes.

Collectively, the data presented do not support substantial adverse impacts of recreational fisheries management on species richness and community diversity in the waterfowl and songbirds present at gravel pit lakes. In a related study from Welsh reservoirs, Cryer et al. (1987) observed only distributional changes of waterfowl in the presence of anglers and no changes in abundance. Similarly, negligible effects of anglers on piscivorous birds at Canadian natural lakes were reported by Somers, Heisler, Doucette, Kjoss, and Brigham (2015). Specifically for gravel pit lakes, Bell et al. (1997) failed to find evidence for impacts of recreational fishing on the community structure of waterfowl, although diving waterfowl in particular were less abundant when anglers and other recreationists were present. In that study, as reported here, habitat quality and lake size were more important for waterfowl diversity than bank use by anglers, and in fact shoreline management supported grazing waterfowl by opening up sites (Bell et al., 1997). This does not mean that recreational fishing will not have impacts on bird populations at all, as the breeding success of certain disturbance-sensitive species might still be impaired (for example Park et al., 2006; Reichholf, 1988). This study was not designed to examine the breeding success of particular species, however, and instead focused on aggregate diversity metrics. Against these, this study did not reveal any significant disturbance effects caused by recreational fisheries.

\section{6 | Limitations}

The strength of the study design is the focus on multiple taxa, which is rare in the recreational ecology literature related to fresh waters. The limitations are that it was not focused on specific species and the sampling design does not answer whether the mobile species detected (e.g. birds or Odonata) reproduced in the lakes studied, or just used them temporarily as feeding or resting habitat. Moreover, because of adjustments in taxa-specific sampling schemes, seasonal taxa (amphibians, Odonata) may have been underestimated in the sampling, and rare species were probably missed (Yoccoz, Nichols, \& Boulinier, 2001). Even if this is the case, however, the conclusions presented are robust because this systematic error affected both lake types.

This study used a comparative approach where lakes were not randomly allocated to either angler-managed lakes or controls. All lakes sampled were from the same geographical area, and the age of the lakes and the wider environmental factors were similar; thus, the key differences between lake types were related to the presence of recreational fishing. This means that the design would have been able to detect strong angling-induced biodiversity effects, had they existed.

A further limitation is that the design did not include entirely unused lakes where recreation is totally prohibited. The present data must be interpreted against the possibility that gravel pits situated in reserves with strictly no human access might show higher species diversity than that found in the lakes sampled. All the lakes were situated in agricultural environments and all were exposed to a certain level of recreational use. Background disturbance might have affected the observed species pool, affecting the detectability of species in the study region. The conclusions of the present work are also confined to the environmental gradients that could be observed. For example, higher intensities of angler use than found in the present work might reveal different results. 
The intensity of recreational use was mainly recorded during weekdays when the field visits took place. Thus, potentially highintensity phases at weekends might be unrepresented. This would actually strengthen our conclusions, however, if the real recreational use of managed lakes was well beyond that considered in this analysis.

\section{7 $\quad$ Conclusions}

This study shows that the co-existence of recreational fisheries and aquatic and riparian biodiversity of high conservation value and richness is possible, at least under the specific ecological conditions of gravel pit lakes in agricultural landscapes. From a conservation perspective, it is suggested that recreational fishing clubs should increasingly use habitat enhancement activities to support fish and other taxa present at gravel pit lakes. The development of diverse shorelines as well as the creation of more gently sloping littoral areas is recommended as actions to be completed during the creation of gravel pit lakes. If these actions are taken, prohibiting recreational fishing is unlikely to produce further conservation benefits if the aim is to create high species diversity, independent of a specific-species identity.

\section{ACKNOWLEDGEMENTS}

We want to thank Sven Matern for his important help at every stage of this study, and we also thank Charlotte Robinchon for her productive dead-wood-sampling internship. We also thank Leander Höhne, Jasper Münnich, Nicola Wegener, Jara Niebuhr, Natalie Arnold, Rachel Fricke, and Stéphane Mutel for their help with field sampling and data analysis. We thank Matthias Emmrich for supervising students in parts of this study. We thank Christopher Monk for immense help with statistical analysis, $\mathrm{R}$ coding, and checking the language of the manuscript. We thank Pieter Lemmens, Miguel Palmer, Jörg Freyhof, and Petr Zajicek for their advice during data processing, analysis, and interpretation. We thank Sabine Hilt and Klaus van de Weyer for training and advice on macrophyte sampling and for help with identification. We thank Tobias Goldhammer and the chemical laboratory of Leibniz Institute of Freshwater Ecology and Inland Fisheries (IGB) for help with water samples. We specifically thank Barbara Stein for her work. We thank Jan Hallermann, Asja Vogt, Alexander Türck, and Jürgen Schreiber for helping with material and equipment. We also thank Angelsportverein Leer u. Umgebung e.V., Bezirksfischereiverband für Ostfriesland e.V., Angler-Verein Nienburg e.V., ASV Neustadt am Rübenberge e.V., Fischereiverein Hannover e. V., Niedersächsisch-Westfälische Anglervereinigung e.V., Ralf Gerken, Heike Vullmer, and the Stiftung Naturschutz im Landkreis Rotenburg (Wümme), Henning Scherfeld, FV Peine-Ilsede u. Umgebung e.V., SFV Helmstedt u. Umgebung e.V., Verein der Sportfischer Verden (Aller) e. V., Verein für Fischerei und Gewässerschutz Schönewörde u. Umgebung e.V., Steffen Göckemeyer, the Xella Kalksandsteinwerke Niedersachsen $\mathrm{GmbH} \&$ Co. KG, Thomas Reimer, Melanie and Heinz H. Nordmeyer, Achaz von Hardenberg, Johann Augustin, Dieter
Klensang, Elke Dammann, Cordula Stein and Holcim Germany, and the Angler Association of Lower Saxony for participating in this study. The work was financed jointly by the German Federal Ministry of Education and Research (BMBF) and the German Federal Agency for Nature Conservation (BfN), with funds granted by the German Federal Ministry for the Environment, Nature Conservation and Nuclear Safety (BMU) within the BAGGERSEE-Projekt (grant no. 01LC1320A; www.baggersee-forschung.de). Additional funding came from the STÖRBAGGER project via the Landesverband Sächsischer Angler e.V., the Landesfischereiverband Bayern e.V., and the Angler Association of Lower Saxony (www.ifishman.de/en/projects/stoerbagger/), the Stiftung Fischerei, Umwelt- und Naturschutz Deutschland (FUND Stiftung), and the BMBF through the Aquatag project (the German Federal Ministry of Education and Research, grant no. 01LC1826E). The funders had no role in the design, analysis, and interpretation of the data. Finally, we thank the Chief Editor Philip J. Boon, Lee Jackson, and anonymous reviewers for constructive feedback on the article that substantially improved our presentation. Open access funding enabled and organized by Projekt DEAL.

\section{ORCID}

Robert Nikolaus (D) https://orcid.org/0000-0002-6639-2743

Malwina Schafft (iD https://orcid.org/0000-0003-0633-4063

Andreas Maday (D) https://orcid.org/0000-0002-0092-8744

Thomas Klefoth (D) https://orcid.org/0000-0003-3659-5336

Christian Wolter (D) https://orcid.org/0000-0002-2819-2900

Robert Arlinghaus (D) https://orcid.org/0000-0003-2861-527X

\section{REFERENCES}

AdV - Working Committee of the Surveying Authorities of the States of the Federal Republic of Germany. (2006) Section 5.4 - Explanations on ATKIS ${ }^{\circledR}$. In: Afflerbach, S. \& Kunze, W. (Eds.) Documentation on the modelling of geoinformation of official surveying and mapping (GeolnfoDok). Vol. 5.1. München, Germany. pp. 1-74.

Altmüller, R. \& Clausnitzer, H.-J. (2010) Rote Liste der Libellen Niedersachsens und Bremens: 2. Fassung, Stand 2007. Informationsdienst Naturschutz Niedersachsen, 30, 211-238.

Arlinghaus, R. (2005) A conceptual framework to identify and understand conflicts in recreational fisheries systems, with implications for sustainable management. Aquatic Resources, Culture and Development, 1, 145-174. ISSN: 1477-903X. https://www.ifishman.de/fileadmin/ user_upload/Publikationen/HU_Berlin_Seite/Publikationen/2005/ Arlinghaus_2005.pdf

Arlinghaus, R., Hühn, D., Pagel, T., Beck, M., Rapp, T. \& Wolter, C. (2017) Fischereilicher Nutzen und gewässerökologische Auswirkungen des Besatzes mit Karpfen $(<e m>$ Cyprinus carpio $</ e m>)$ in stehenden Gewässern: Ergebnisse und Schlussfolgerungen aktueller Ganzseeexperimente und Meta-Analysen. Fischerei Und Fischmarkt in Mecklenburg-Vorpommern, 1, 36-46. https://www.lvbmv.de/ download/zeitschrift/FF_1_2017.pdf

Arlinghaus, R., Müller, R., Rapp, T. \& Wolter, C. (2017) Nachhaltiges Management von Angelgewässern: Ein Praxisleitfaden (Band 30). Berlin, Germany: Leibniz-Institute of Freshwater Ecology and Inland Fisheries (IGB).

Bajer, P.G., Beck, M.W., Cross, T.K., Koch, J.D., Bartodziej, W.M. \& Sorensen, P.W. (2016) Biological invasion by a benthivorous fish reduced the cover and species richness of aquatic plants in most lakes 
of a large north American ecoregion. Global Change Biology, 22, 3937-3947. https://doi.org/10.1111/gcb.13377

Beardmore, B., Hunt, L.M., Haider, W., Dorow, M. \& Arlinghaus, R. (2015) Effectively managing angler satisfaction in recreational fisheries requires understanding the fish species and the anglers. Canadian Journal of Fisheries and Aquatic Sciences, 72, 500-513. https://doi.org/10. 1139/cjfas-2014-0177

Bell, M.C., Delany, S.N., Millett, M.C. \& Pollitt, M.S. (1997) Wintering waterfowl community structure and the characteristics of gravel pit lakes. Wildlife Biology, 3, 65-78. https://doi.org/10.2981/wlb. 1997.009

Blanchet, F.G., Legendre, P. \& Borcard, D. (2008) Forward selection of explanatory variables. Ecology, 89, 2623-2632. https://doi.org/10. 1890/07-0986.1

Braun-Blanquet, J. (1964). Pflanzensoziologie: Grundzüge der Vegetationskunde. In Pflanzensoziologie (3rd ed.). Wien, Austria: Springer.

Council of the European Communities. (1992) Council Directive 92/43/EEC of 21 May 1992 on the conservation of natural habitats and of wild fauna and flora. Official Journal of the European Communities, L206, 7-50. https://doi.org/10.1017/ СВ09780511610851.039

Cryer, M., Linley, N.W., Ward, R.M., Stratford, J.O. \& Randerson, P.F. (1987) Disturbance of overwintering wildfowl by anglers at two reservoir sites in South Wales. Bird Study, 34, 191-199. https://doi.org/10. 1080/00063658709476961

Cucherousset, J., Boulêtreau, S., Azémar, F., Compin, A., Guillaume, M. \& Santoul, F. (2012) "Freshwater killer whales": Beaching behavior of an alien fish to hunt land birds. PLoS ONE, 7, 1-6. https://doi.org/10. 1371/journal.pone.0050840

Cyrus, E., Klefoth, T., Wolter, C., Nikolaus, R., Matern, S., Schafft, M., Arlinghaus, R. (2020) Baggerseen sind Refugien für die Artenvielfalt. Wasser und Abfall, 22(10), 30-37. https://doi.org/10.1007/s35152020-0265-y

Damnjanović, B., Novković, M., Vesić, A., Živković, M., Radulović, S., Vukov, D. \& Cvijanović, D. (2018) Biodiversity-friendly designs for gravel pit lakes along the Drina River floodplain (the middle Danube Basin, Serbia). Wetlands Ecology and Management, 27, 1-22. https:// doi.org/10.1007/s11273-018-9641-8

Dear, E.J., Guay, P.-J., Robinson, R.W. \& Weston, M.A. (2015) Distance from shore positively influences alert distance in three wetland bird species. Wetlands Ecology and Management, 23, 315-318. https://doi. org/10.1007/s11273-014-9376-0

DeBoom, C.S. \& Wahl, D.H. (2013) Effects of coarse woody habitat complexity on predator-prey interactions of four freshwater fish species. Transactions of the American Fisheries Society, 142, 1602-1614. https://doi.org/10.1080/00028487.2013.820219

Díaz, S., Settele, J., Brondizio, E.S., Ngo, H.T., Agard, J., Arneth, A. \& Zayas, C.N. (2019) Pervasive human-driven decline of life on earth points to the need for transformative change. Science, 366, eaax3100. https://doi.org/10.1126/science.aax3100

Dierschke, V. (2016) Welcher Vogel ist das? - 170 Vögel einfach bestimmen, 3. Auflage edition. Stuttgart, Germany: Franckh-Kosmos.

DIN EN 1484. (1997) Water analysis - guidelines for the determination of total organic carbon (TOC) and dissolved organic carbon (DOC). Berlin, Germany: Beuth Verlag GmbH. https://dx.doi.org/10.31030/3042067

DIN EN ISO 13395. (1996) Water quality - determination of nitrite nitrogen and nitrate nitrogen and the sum of both by flow analysis (CFA and FIA) and spectrometric detection (ISO 13395:1996). Berlin, Germany: Beuth Verlag GmbH.

Dudgeon, D., Arthington, A.H., Gessner, M.O., Kawabata, Z.-I., Knowler, D. J., Lévêque, C. \& Sullivan, C.A. (2006) Freshwater biodiversity: Importance, threats, status and conservation challenges. Biological Reviews of the Cambridge Philosophical Society, 81, 163-182. https://doi.org/10. $1017 /$ S1464793105006950
EN ISO 11732. (2005) Water quality-determination of ammonium nitrogen-method by flow analysis (CFA and FIA) and spectrometric detection (ISO 11732:1997). Berlin, Germany: Beuth Verlag GmbH.

EN ISO 6878. (2004) Water quality-determination of phosphorusammonium molybdate spectrometric method (ISO 6878:1998). Berlin, Germany: Beuth Verlag GmbH.

European Aggregates Association (UEPG). (2017) Estimates of Aggregates Production Data 2017. Retrieved June 17, 2020. http://www.uepg.eu/ statistics/estimates-of-production-data/data-2017

Franson, J.C., Hansen, S.P., Creekmore, T.E., Brand, C.J., Evers, D.C., Duerr, A.E. \& DeStefano, S. (2003) Lead fishing weights and other fishing tackle in selected waterbirds. Waterbirds: the International Journal of Waterbird Biology, 26, 345-352. https://doi.org/10.1675/15244695(2003)026[0345:LFWAOF]2.0.CO;2

Garve, E. (2004) Rote Liste und Florenliste der Farn- und Blütenpflanzen in Niedersachsen und Bremen, 5. Fassung, Stand 1.3.2004. Informationsdienst Naturschutz Niedersachsen, 24, 1-76.

Gräler, B., Pebesma, E. \& Heuvelink, G. (2016) Spatio-temporal interpolation using gstat. The R Journal, 8, 204-218. https://doi.org/10.32614/ RJ-2016-014

Granek, E.F., Madin, E.M.P., Brown, M.A., Figueira, W., Cameron, D.S., Hogan, Z. \& Arlinghaus, R. (2008) Engaging recreational fishers in management and conservation: Global case studies. Conservation Biology, 22, 1125-1134. https://doi.org/10.1111/j.1523-1739.2008.00977.x

Hecnar, S.J. \& M'Closkey, R.T. (1997) The effects of predatory fish on amphibian species richness and distribution. Biological Conservation, 79, 123-131. https://doi.org/10.1016/s0006-3207(96)00113-9

Holtmann, L., Juchem, M., Brüggeshemke, J., Möhlmeyer, A., Fartmann, T. (2018) Stormwater ponds promote dragonfly (Odonata) species richness and density in urban areas. Ecological Engineering, 118, 1-11. https://doi.org/10.1016/j.ecoleng.2017.12.028

Holtmann, L., Kerler, K., Wolfgart, L., Schmidt, C. \& Fartmann, T. (2019) Habitat heterogeneity determines plant species richness in urban stormwater ponds. Ecological Engineering, 138, 434-443. https://doi. org/10.1016/j.ecoleng.2019.07.035

Kaufmann, P.R. \& Whittier, T.R. (1997) Habitat assessment. In: Baker, J.R., Peck, D.V. \& Sutton, D.W. (Eds.) Environmental monitoring and assessment program - surface waters: field operations manual for lakes (pp. 5-1 to 5-26). Washington, D.C.: U.S: Environmental Protection Agency.

Kaufmann, P.R., Hughes, R.M., Whittier, T.R., Bryce, S.A. \& Paulsen, S.G. (2014) Relevance of lake physical habitat indices to fish and riparian birds. Lake and Reservoir Management, 30, 177-191. https://doi.org/ 10.1080/10402381.2013.877544

Knight, R.L., Anderson, D.P. \& Marr, N.V. (1991) Responses of an avia scavenging guild to anglers. Biological Conservation, 56, 195205. https://doi.org/10.1016/0006-3207(91)90017-4

Knorp, N.E. \& Dorn, N.J. (2016) Mosquitofish predation and aquatic vegetation determine emergence patterns of dragonfly assemblages. Freshwater Science, 35, 114-125. https://doi.org/10.1086/684678

Kohler, A. (1978) Methoden der Kartierung von Flora und Vegetation von Süßwasserbiotopen. Landschaft + Stadt, 10, 73-85.

Korsch, H., Doege, A., Raabe, U. \& van de Weyer, K. (2013) Rote Liste der Armleuchteralgen (Charophyceae) Deutschlands 3. Fassung, Stand: Dezember 2012. Hausknechtia, 17, 1-32.

Krüger, T. \& Nipkow, M. (2015) Rote Liste der in Niedersachsen und Bremen gefährdeten Brutvogelarten, 8. Fassung, Stand 2015. Informationsdienst Naturschutz Niedersachsen, 35, 181-256.

Lehmann, A.W. \& Nüss, J.H. (2015) Libellen - Bestimmungsschlüssel für Nord- und Mitteleuropa, sixth edition. Göttingen, Germany: Deutscher Jugendbund für Naturbeobachtungen.

Lemmens, P., Mergeay, J., De Bie, T., Van Wichelen, J., De Meester, L. \& Declerck, S.A.J. (2013) How to maximally support local and regional biodiversity in applied conservation? Insights from pond management. PLoS ONE, 8, e72538. https://doi.org/10.1371/journal.pone.0072538 
Lewin, W.-C., Mehner, T., Ritterbusch, D. \& Brämick, U. (2014) The influence of anthropogenic shoreline changes on the littoral abundance of fish species in German lowland lakes varying in depth as determined by boosted regression trees. Hydrobiologia, 724, 293-306. https://doi. org/10.1007/s10750-013-1746-8

Mantoura, R.F.C. \& Llewellyn, C.A. (1983) The rapid determination of algal chlorophyll and carotenoid pigments and their breakdown products in natural waters by reverse-phase high-performance liquid chromatography. Analytica Chimica Acta, 151, 297-314. https://doi.org/10. 1016/S0003-2670(00)80092-6

Matern, S., Emmrich, M., Klefoth, T., Wolter, C., Nikolaus, R., Wegener, N. \& Arlinghaus, R. (2019) Effect of recreational-fisheries management on fish biodiversity in gravel pit lakes, with contrasts to unmanaged lakes. Journal of Fish Biology, 94, 865-881. https://doi. org/10.1111/jfb.13989

Matthews, W.J. (1986) Fish faunal "breaks" and stream order in the eastern and central United States. Environmental Biology of Fishes, 17, 81-92. https://doi.org/10.1007/BF00001739

McFadden, T.N., Herrera, A.G. \& Navedo, J.G. (2017) Waterbird responses to regular passage of a birdwatching tour boat: Implications for wetland management. Journal for Nature Conservation, 40, 42-48. https:// doi.org/10.1016/J.JNC.2017.09.004

Meyerhoff, J., Klefoth, T. \& Arlinghaus, R. (2019) The value artificial lake ecosystems provide to recreational anglers: Implications for management of biodiversity and outdoor recreation. Journal of Environmental Management, 252, 109580. https://doi.org/10.1016/j.jenvman.2019. 109580

Miller, S.A. \& Crowl, T.A. (2006) Effects of common carp (Cyprinus carpio) on macrophytes and invertebrate communities in a shallow lake. Freshwater Biology, 51, 85-94. https://doi.org/10.1007/s00198-005-1915-3

Monk, C.D. \& Gabrielson, F.C.J. (1985) Effects of shade, litter and root competition on old-field vegetation in South Carolina. Bulletin of the Torrey Botanical Club, 112, 383-392.

Müller, H. (2012) Zulässigkeit und Grenzen der Ausgestaltung/Einschränkung von Fischereirechten an Baggerseen [Rechtsgutachten]. Bayreuth/München, Germany: Bezirksfischereiverband Oberfranken e.V., Landesfischereiverband Bayern e.V.

Müller, Z., Jakab, T., Tóth, A., Dévai, G., Szállassy, N., Kiss, B. \& Horváth, R. (2003) Effect of sports fisherman activities on dragonfly assemblages on a Hungarian river floodplain. Biodiversity and Conservation, 12, 167-179.

Murphy, J. \& Riley, J.P. (1962) A modified single solution method for the determination of phosphate in natural water. Analytica Chimica Acta, 27, 31-36.

Neter, J., Kutner, M.H., Nachtsheim, C.J. \& Wasserman, W. (1996) Applied linear statistical models, Fourth edition. Chicago, IL: Irwin.

Oertli, B. (2018) Editorial: Freshwater biodiversity conservation: The role of artificial ponds in the 21st century. Aquatic Conservation: Marine and Freshwater Ecosystems, 28, 264-269. https://doi.org/10.1002/ aqc. 2902

Oertli, B., Joye, D.A., Castella, E., Juge, R., Cambin, D. \& Lachavanne, J.-B. (2002) Does size matter? The relationship between pond area and biodiversity. Biological Conservation, 104, 59-70.

Oksanen, J., Blanchet, F.G., Friendly, M., Kindt, R., Legendre, P., McGlinn, D. \& Wagner, H. (2018) Vegan: Community ecology package (R package version 2.5-3). Wien, Austria: R Foundation for Statistical Computing.

O'Toole, A.C., Hanson, K.C. \& Cooke, S.J. (2009) The effect of shoreline recreational angling activities on aquatic and riparian habitat within an urban environment: Implications for conservation and management. Environmental Management, 44, 324-334. https://doi.org/10.1007/ s00267-009-9299-3

Paracuellos, M. (2006) Relationships of songbird occupation with habitat configuration and bird abundance in patchy reed beds. Ardea, 94, 87-98.
Park, J.-H., Park, H.-W., Sung, H.-C. \& Park, S.-R. (2006) Effect of fishing activity on nest selection and density of waterfowls in Namyang Lake. Journal of Ecology and Field Biology, 29, 213-217.

Paszkowski, C.A. \& Tonn, W.M. (2000) Effects of lake size, environment, and fish assemblage on species richness of aquatic birds. Verhandlungen der Internationalen Vereinigung für theoretische und angewandte Limnologie, 27, 178-182. https://doi.org/10.1080/ 03680770.1998 .11901222

Pielou, E.C. (1969) An introduction to mathematical ecology. New York City, NY: Wiley-Interscience.

Podloucky, R. \& Fischer, C. (2013) Rote listen und Gesamtartenlisten der Amphibien und Reptilien in Niedersachsen und Bremen, 4. Fassung. Informationsdienst Naturschutz Niedersachsen, 4.

Preising, E., Vahle, H.-C., Brandes, D., Hofmeister, H., Tüxen, J., \& Weber, H. E. (1990). Die Pflanzengesellschaften Niedersachsens Bestandsentwicklung, Gefährdung und Schutzprobleme: Salzpflanzengesellschaften der Meeresküste und des Binnenlandes \& Wasser- und Sumpfpflanzengesellschaften des Süßwassers. Naturschutz Landschaftspflege Niedersachsens, 20/7 \& 8, 1-44 \& 47-161. Hannover, Germany: Niedersächsisches Landesamt für Ökologie - Naturschutz.

Randler, C. (2006) Disturbances by dog barking increase vigilance in coots Fulica atra. European Journal of Wildlife Research, 52, 265-270. https:// doi.org/10.1007/s10344-006-0049-z

Ravn, H.D., Lauridsen, T.L., Jepsen, N., Jeppesen, E., Hansen, P.G., Hansen, J.G. \& Berg, S. (2019) A comparative study of three different methods for assessing fish communities in a small eutrophic lake. Ecology of Freshwater Fish, 28, 341-352. https://doi.org/10.1111/eff. 12457

Reichholf, J.H. (1988) Effects of anglers on the breeding of water birds in the internationally important wetland "lower Inn River". Vogelwelt, 109, 206-221.

Reid, A.J., Carlson, A.K., Creed, I.F., Eliason, E.J., Gell, P.A., Johnson, P.T.J. \& Cooke, S.J. (2019) Emerging threats and persistent conservation challenges for freshwater biodiversity. Biological Reviews, 94, 849-873. https://doi.org/10.1111/brv.12480

Rempel, R.S., Hobson, K.A., Holborn, G., Van Wilgenburg, S.L. \& Elliott, J. (2005) Bioacoustic monitoring of forest songbirds: Interpreter variability and effects of configuration and digital processing methods in the laboratory. Journal of Field Ornithology, 76, 1-11. https://doi.org/10. 1648/0273-8570-76.1.1

Remsburg, A.J. \& Turner, M.G. (2009) Aquatic and terrestrial drivers of dragonfly (Odonata) assemblages within and among north-temperate lakes. Journal of the North American Benthological Society, 28, 44-56. https://doi.org/10.1899/08-004.1

Riedmüller, U., Hoehn, E. \& Mischke, U. (2013) Auswerte-Tool für die Trophie-Klassifikation von Seen. Trophie-Index nach LAWA. (computer software; version 1.0). Freiburg/Berlin, Germany: Limnologie-Büro Hoehn/Leibniz Institute of Freshwater Ecology and Inland Fisheries (IGB).

$R$ Core Team. (2013) $R-A$ language and environment for statistical computing (3.5.1). Wien, Austria: R Foundation for Statistical Computing.

Saulnier-Talbot, É. \& Lavoie, I. (2018) Uncharted waters: The rise of human-made aquatic environments in the age of the "Anthropocene". Anthropocene, 23, 29-42. https://doi.org/10.1016/j.ancene.2018. 07.003

Schaumburg, J., Schranz, C., Stelzer, D. \& Vogel, A. (2014) Verfahrensanleitung für die ökologische Bewertung von Seen zur Umsetzung der EG-Wasserrahmenrichtlinie: Makrophyten \& Phytobenthos (version 10). Augsburg/Wielenbach, Germany: Länderarbeitsgemeinschaft Wasser (LAWA).

Schlüpmann, M. (2005) Bestimmungshilfen: Faden- und TeichmolchWeibchen, Braunfrösche, Wasser- oder Grünfrösche, Eidechsen, Schlingnatter und Kreuzotter, Ringelnatter- Unterarten. Rundbrief Zur Herpetofauna von Nordrhein-Westfalen, 28, 1-38. 
Sears, J. (1988) Regional and seasonal variations in lead poisoning in the mute swan (Cygnus olor) in relation to the distribution of lead and lead weights, in the Thames area, England. Biological Conservation, 46, 115-134.

Shulse, C.D., Semlitsch, R.D., Trauth, K.M. \& Williams, A.D. (2010) Influences of design and landscape placement parameters on amphibian abundance in constructed wetlands. Wetlands, 30, 915-928. https:// doi.org/10.1007/s13157-010-0069-z

Šidák, Z. (1967) Rectangular confidence regions for the means of multivariate normal distributions. Journal of the American Statistical Association 62, 626-633. https://doi.org/10.1080/01621459.1967.10482935

Somers, C.M., Heisler, L.M., Doucette, J.L., Kjoss, V.A. \& Brigham, R.M. (2015) Lake use by three avian piscivores and humans: Implications for angler perception and conservation. Journal of Open Ornithology, 8, 10-21.

Sørensen, T.A. (1948) A method of establishing groups of equal amplitude in plant sociology based on similarity of species content and its application to analyses of the vegetation on Danish commons. Biologiske Skrifter, 5, 1-34.

Spohn, M., Golte-Bechtle, M. \& Spohn, R. (2015) Was blüht denn da? (59. Auflage). Stuttgart, Germany: Franckh-Kosmos.

Spyra, A. \& Strzelec, M. (2019) The implications of the impact of the recreational use of forest mining ponds on benthic invertebrates with special emphasis on gastropods. Biologia, 1-12. https://doi.org/10.2478/ s11756-019-00221-2

Trochet, A., Moulherat, S., Calvez, O., Stevens, V., Clobert, J. \& Schmeller, D. (2014) A database of life-history traits of European amphibians. Biodiversity Data Journal, 2, e4123. https://doi.org/10. 3897/BDJ.2.e4123

Van de Weyer, K. \& Schmitt, C. (2011) Bestimmungsschlüssel für die aquatischen Makrophyten (Gefäßpflanzen, Armleuchteralgen und Moose) in Deutschland - Band 1: Bestimmungsschlüssel. Fachbeiträge Des LUGV, 119, 164.

Van de Weyer, K., Meis, S. \& Krautkrämer, V. (2015) Die Makrophyten des Großen Stechlinsees, des Wummsees und des Wittwesees. Fachbeiträge des LUGV, 145, 1-92.

Van der Maarel, E. (1979) Transformation of cover-abundance values in phytosociology and its effects on community similarity. Vegetatio, 39 97-114. https://doi.org/10.1007/bf00052021

Venohr, M., Langhans, S.D., Peters, O., Hölker, F., Arlinghaus, R., Mitchell, L. \& Wolter, C. (2018) The underestimated dynamics and impacts of water-based recreational activities on freshwater ecosystems. Environmental Reviews, 26, 199-213. https://doi.org/10.1139/ er-2017-0024

Vilizzi, L., Tarkan, A.S. \& Copp, G.H. (2015) Experimental evidence from causal criteria analysis for the effects of common carp (Cyprinus carpio) on freshwater ecosystems: A global perspective. Reviews in Fisheries Science and Aquaculture, 23, 253-290. https://doi.org/10.1080/ 23308249.2015.1051214

Wilson, A.M., Barr, J. \& Zagorski, M. (2017) The feasibility of counting songbirds using unmanned aerial vehicles. The Auk, 134, 350-362. https://doi.org/10.1642/auk-16-216.1

Winfield, I. J. (2004). Fish in the littoral zone: Ecology, threats and management. Limnologica, 34, 124-131. https://doi.org/10.1016/S00759511(04)80031-8

Wright, S.W. (1991) Improved HPLC method for the analysis of chlorophylls and carotenoids from marine phytoplankton. Marine Ecology Progress Series, 77, 183-196. https://doi.org/10.3354/meps077183

Yoccoz, N. G., Nichols, J. D., \& Boulinier, T. (2001). Monitoring of biological diversity in space and time. Trends in Ecology \& Evolution, 16, 446-453. https://doi.org/10.1016/S0169-5347(01)02205-4

Zhao, T., Grenouillet, G., Pool, T., Tudesque, L. \& Cucherousset, J. (2016) Environmental determinants of fish community structure in gravel pit lakes. Ecology of Freshwater Fish, 25, 412-421. https://doi.org/10. 1111/eff.12222

\section{SUPPORTING INFORMATION}

Additional supporting information may be found online in the Supporting Information section at the end of this article.

How to cite this article: Nikolaus R, Schafft M, Maday A, Klefoth T, Wolter C, Arlinghaus R. Status of aquatic and riparian biodiversity in artificial lake ecosystems with and without management for recreational fisheries: Implications for conservation. Aquatic Conserv: Mar Freshw Ecosyst. 2021; 31:153-172. https://doi.org/10.1002/aqc.3481 